\title{
RESPONSE OF ECTOMYCORRHIZAL FUNGI TO INORGANIC AND ORGANIC FORMS OF NITROGEN AND PHOSPHORUS
}

Christa M. Luokkala

Michigan Technological University

Follow this and additional works at: https://digitalcommons.mtu.edu/etds

Part of the Forest Sciences Commons

Copyright 2012 Christa M. Luokkala

\section{Recommended Citation}

Luokkala, Christa M., "RESPONSE OF ECTOMYCORRHIZAL FUNGI TO INORGANIC AND ORGANIC FORMS OF NITROGEN AND PHOSPHORUS", Master's report, Michigan Technological University, 2012.

https://doi.org/10.37099/mtu.dc.etds/611

Follow this and additional works at: https://digitalcommons.mtu.edu/etds

8 Part of the Forest Sciences Commons 


\title{
RESPONSE OF ECTOMYCORRHIZAL FUNGI TO INORGANIC AND ORGANIC FORMS OF NITROGEN AND PHOSPHORUS
}

\author{
By \\ Christa M. Luokkala

\begin{abstract}
A REPORT
Submitted in partial fulfillment of the requirements for the degree of MASTER OF SCIENCE

In Applied Ecology
\end{abstract}

MICHIGAN TECHNOLOGICAL UNIVERSITY

2012

(C) 2012 Christa M. Luokkala 
This report has been approved in partial fulfillment of the requirements for the Degree of MASTER OF SCIENCE in Applied Ecology.

School of Forest Resources and Environmental Science

\author{
Report Advisor: $\quad$ Dr. Erik A. Lilleskov \\ Committee Member: $\quad$ Dr. Susan A. Bagley \\ Committee Member: $\quad$ Dr. Dana L. Richter \\ Committee Member: Dr. Christopher W. Swanston
}

School Dean: $\quad$ Dr. Terry L. Sharik 


\section{Table of Contents}

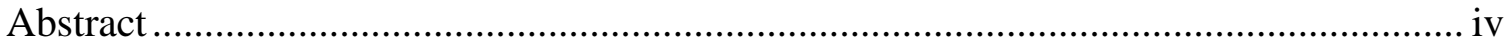

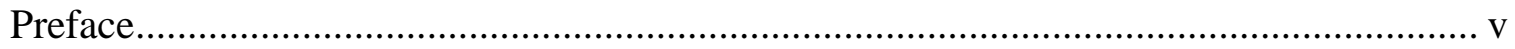

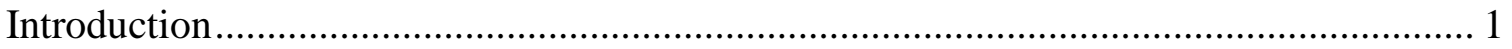

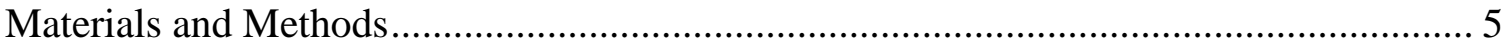

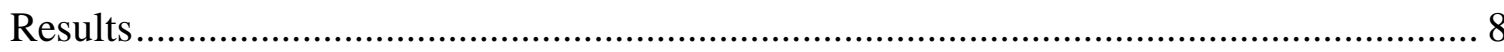

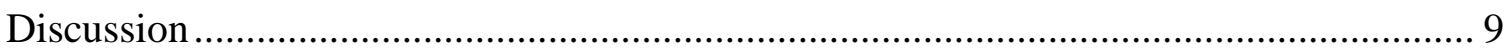

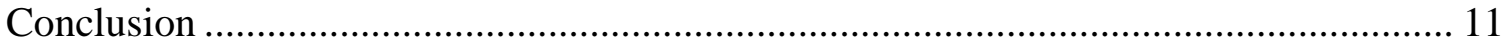

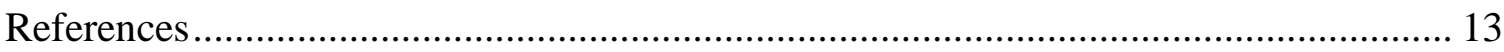

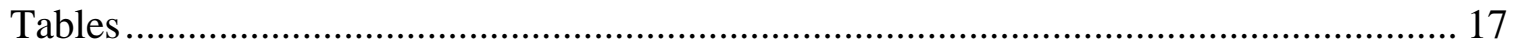

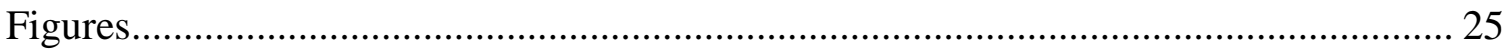

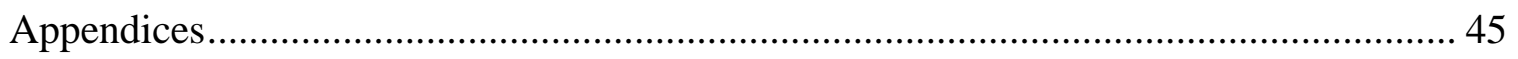

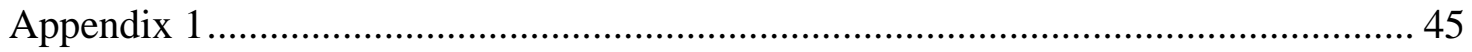

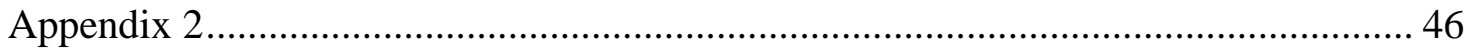

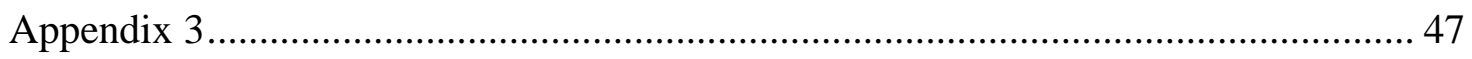

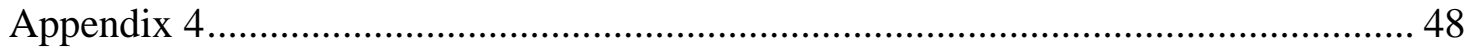

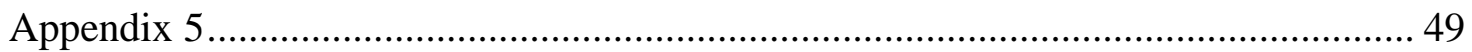




\begin{abstract}
The nutrient uptake response of ectomycorrhizal fungi (ECM) to different nutrient substrates is a driving force in ecosystem nutrient cycling. We hypothesized that taxa from low nitrogen $(\mathrm{N})$ soils would be more likely to use organic $\mathrm{N}$ compared to taxa from high $\mathrm{N}$ soils, and that taxa from high $\mathrm{N}$ would be more likely to use organic phosphorus (P) sources when compared to the ECM dominant in low $\mathrm{N}$ soils. This study focuses on the growth response of ECM species collected over a $\mathrm{N}$ gradient to different forms of $\mathrm{N}$ and $\mathrm{P}$ nutrient substrates and whether ECM growth in a particular nutrient source can be related to how the ECM fungi have responded to elevated $\mathrm{N}$ in the field. This study found a mixed ECM response to organic and inorganic $\mathrm{N}$ and $\mathrm{P}$ treatments. High affinity $\mathrm{N}$ taxa expected to respond positively to inorganic $\mathrm{N}$ produced the phosphatase enzyme to take up organic phosphorus, but not all low affinity $\mathrm{N}$ taxa expected to negatively respond to organic $\mathrm{P}$ produced the protease enzyme to take up organic $\mathrm{N}$. Interspecific variability was displayed by some high and low affinity $\mathrm{N}$ taxa responded and ECM intraspecific variability in response to $\mathrm{N}$ and $\mathrm{P}$ treatments was also noted. Future analysis of may show more evident ECM response patterns to inorganic and organic forms of $\mathrm{N}$ and $\mathrm{P}$.
\end{abstract}




\section{Preface}

This report is planned for publication in an ecological journal. The text was written in first-person plural to give credit to multiple people that have contributed to this research and will be acknowledged as co-authors on the publication. 


\section{Introduction}

Research is limited on broad spectrum comparisons of ectomycorrhizal fungal (ECM) species utilizing different sources of nitrogen $(\mathrm{N})$ and phosphorus $(\mathrm{P})$. Most studies only compare a few species, and P utilization is poorly understood for many ECM species. Studies have provided data on ECM affinity towards survival under specific concentrations of $\mathrm{N}$ and $\mathrm{P}$. Existing literature shows mycorrhizal fungi play a major role in plant N uptake in N-poor environments (Smith \& Read 1997). While a higher amount of ECM proficient at producing phosphatase have been identified in areas of higher $\mathrm{P}$ immobilization (Conn \& Dighton 2000), ECM enzyme production patterns have shown less nitrogenous protein use by dominant ECM from sites of high $\mathrm{N}$ concentrations (Taylor et al. 2000, Lilleskov et al. 2002b).

\section{Ectomycorrhizal fungal nutrient uptake}

Ectomycorrhizal fungi are known for their influence in producing soluble substrates for cellular assimilation. Ectomycorrhizal fungi can short-circuit the $\mathrm{N}$ cycle by directly accessing organic $\mathrm{N}$ (amino acids and peptides) via extracellular N-mobilizing enzyme production (Figure 1) (Smith \& Read 2008; Chalot \& Brun 1998; Näsholm \& Persson 2001). Through extracellular enzyme production such as proteases and phosphatases, ECM are capable of improving inorganic $\mathrm{N}$ uptake and access to previously unavailable recalcitrant organic N and P for their hosts/symbionts (Read 1991; Chalot \& Brun 1998). ECM amino acid cycling is regulated by the presence of a symbiont, N presence, and soil pH levels (Chalot and Brun 1998). The optimality of the ECM extracellular enzyme production and high proteolytic potential is important to consider as soil $\mathrm{N}$ availability is altered. Moreover, it is important to consider how ECM under environmental stress can redirect its energy towards optimizing protease and phosphatase production. Pure culture research has shown substantial variation in phosphatase ECM activity (Pacheco et al. 1991).

Nitrogen is one of the main controlling factors in not only tissue growth but also organismal survival. In forest soils, over $95 \%$ of soil $\mathrm{N}$ is in organic form and less than 
$5 \%$ of total $\mathrm{N}$ in soil is in inorganic ammonium $\left(\mathrm{NH}_{4}{ }^{+}\right)$and nitrate $\left(\mathrm{NO}_{3}{ }^{-}\right)$forms. Soil $\mathrm{N}$ locked up in organic forms requires ECM proteolytic enzyme production to access this $\mathrm{N}$ pool (Chalot \& Brun 1998).

Ectomycorrhizal fungal species differ in their response to elevated N. Increased $\mathrm{N}$ over time causes ECM sporocarp production to change (Lilleskov et al. 2001) and influences community structure (Lilleskov et al. 2001 and 2002a). Considerable attention has been given to understanding how different ECM species respond to varying concentrations of $\mathrm{N}$ and different forms of $\mathrm{N}$ (Lilleskov et al. 2011 and references therein).

Phosphorus is also a limiting nutrient due to its role in nutrient transport and energy transfer. Ectomycorrhizal hyphal patches are sinks for P (phosphate fed into the growing hyphae) (Read 1991), and when P substrate levels decrease, the enzyme group acid phosphatases are activated in ECM to facilitate P uptake (Pacheco, et al. 1991). Research is lacking concerning the role different forms and availability of P influence ECM species development and dominance (Marschner and Dell 1994; Treseder 2004).

Another consideration in ECM survival and/or dominance is the form of nutrients available for the ECM to take up. There appears to be no studies simultaneously comparing ECM species preference for inorganic and organic forms of both $\mathrm{N}$ and $\mathrm{P}$. N and $\mathrm{P}$ must be present in suitable concentrations to provide the building blocks for cellular growth and repair. Inorganic $\mathrm{N}$ occurs as ammonium $\left(\mathrm{NH}^{4+}\right)$ that dominates in acid soils and nitrate $\left(\mathrm{NO}_{3}{ }^{-}\right)$(Brady and Weil 2008). Organic $\mathrm{N}$, which is the dominant form of $\mathrm{N}$ in soil, includes proteins (amino acids and peptides) that most ECM are capable of taking up by extracellular enzyme production (Smith and Read 2008). Inorganic $\mathrm{P}$ is predominantly present in the form of phosphate $\left(\mathrm{PO}_{4}{ }^{-}\right)$and has been shown in high amounts to inhibit phosphatase production in ECM (Sinsabaugh and Linkins 1992). Organic $P$ is ubiquitous across all environments primarily in a variety of diester and monoester bonded phosphate groups. Monoester bonded phosphates, including inositol phosphates, require ECM to produce phosphomonoesterase enzymes to facilitate the uptake of P (Turner et al. 2002, Read and Perez-Moreno 2003). N and P forms can be 
present in varying amounts that may lead to interspecific variation and specialization in how fungal species respond to different forms of $\mathrm{N}$ and $\mathrm{P}$.

\section{Ectomycorrhizal fungal culturing}

Nutrient uptake by ECM has received critical attention on a species by species basis (Jentschke et al. 2001, Read and Perez-Moreno 2003, Treseder 2004). However, laboratory experiments quantifying nutrient uptake affinities by ECM collected from nutrient gradients are very rare in the literature (Wallenda and Read 1999). One reason for the lack of reports comparing interspecific species responses to different forms of nutrients is due to the vast preparatory work involved in such experiments. ECM fungal collecting involves a basic knowledge on ECM sporocarp and root tip morphology, a system to keep track of the reference fruiting body along with storage space to incubate live cultures, and the ability to extract tissue from the sporocarp or root tip to plate on agar plates under sterile conditions. ECM tissue growth involves an extensive amount of labor and the continuous concern over sterile workplace conditions. ECM identification is a step-by-step process requiring skilled labor for confirming culture viability and advanced molecular techniques to confirm the identification and lack of contamination of a fungal isolate (Heinonen-Tanski and Holopainen 1991; Rygiewicz and Armstrong 1991; Smith and Onions 1994). After all of this, an experiment can finally be conducted on the viable, uncontaminated, and identified fungi.

The most ideal medium form for culturing ECM after identification is in liquid culture tubes due to the reduced surface area exposed to the environment, the conservation of laboratory space, and the eliminated occurrence for dehydration. Liquid culture assists in reducing the growth substrate heterogeneity typical of soil. Repeated measurements on single root tips can be assayed over time with reproducibility and no loss of enzyme activity, because there are membrane-bound enzymes on the ECM. Thus, enzymes are not lost over repeated measures when transferred from one liquid substrate to the next (Pritsch, et al. 2004). Several ECM including Thelephora, Clitocybe, Tricholoma, and Hebeloma grow well after storage in sterile water, and Leccinum and Suillus had 100\% viability after storage (Richter and Brun 1989). Richter (2008) has also 
shown ECM are viable after being stored in sterile water for twenty years. Furthermore, culturing ECM in test tubes containing liquid media eliminates the necessity for measuring evaporation from dishes (Rangel-Castro et al. 2002).

\section{Study description}

We chose ECM fungal taxa from across a $\mathrm{N}$ gradient to investigate their growth response to inorganic $\mathrm{N}$, organic $\mathrm{N}$, inorganic $\mathrm{P}$, and organic $\mathrm{P}$ sources. This report analyzes eight ECM taxa from this study. Intraspecific ECM physiological variation can be underestimated if only one strain of each species is used experimentally (Cairney 1999). There is some understanding on how these fungal isolates respond to different forms of inorganic and organic $\mathrm{N}$ and $\mathrm{P}$ (Table 1). This study represents a broad range of ECM fungi in temperate forest soils. We chose several species to represent different $\mathrm{N}$ and P uptake capabilities. Paxillus involutus is an ideal ECM for in vitro experimentation due to its fast growth. Less is known about ECM more difficult to grow in pure culture such as Cortinarius, Lactarius, Russula, Tomentella, and Tricholoma (Nygren et al. 2007).

The overall study examines the growth response of 24 ECM species collected over a $\mathrm{N}$ gradient to different forms of $\mathrm{N}$ and $\mathrm{P}$ and whether ECM growth in a particular nutrient source can be related to how the ECM fungi have responded to elevated $\mathrm{N}$ in the field (Table 3). The primary objective of this study focuses on the growth response of ECM species to different nutrient substrates. Deciphering ECM response to nutrient sources will improve understanding of the internal $\mathrm{N}$ cycling which is the critical driver of ECM community change. The secondary objective of this study delves into inter- and intraspecific variation in growth on different $\mathrm{N}$ and $\mathrm{P}$ forms depending on the $\mathrm{N}$ availability at the site of origin. Hypotheses: The ectomycorrhizal fungi from low $N$ soils will utilize organic $N$ more efficiently than ectomycorrhizal fungi from high $N$ soils. In contrast, the ectomycorrhizal fungi from high $N$ soils will utilize organic P more efficiently than ectomycorrhizal fungi from low $N$ soils. 


\section{Materials and Methods}

\section{Study area}

The study sites were located on the Kenai Peninsula, in Alaska, USA (Figure 2 and for details of study area see Lilleskov et.al. 2001, 2002a, and 2002b). An atmospheric ammonium deposition gradient exists near a fertilizer manufacturing facility with increased levels of $\mathrm{N}$ deposition, resulting in higher soil inorganic $\mathrm{N}$ availability (Lilleskov et.al. 2002a). Sites were established in 1994 and are dominated by Picea glauca (white spruce) and Betula kenaica (Kenai paper birch) on well drained, fine sandy loam glacial outwash (Lilleskov et al. 2001).

\section{Field sampling and direct sequence analysis}

Sporocarps and root tips were collected by Erik Lilleskov in August 2006 and 2007 at five sites from across this gradient. Sporocarps and root tips were located at each site in close proximity to mature white spruce trees. Sporocarps previously identified in Lilleskov et al. (2001) were collected preferentially. Sections of forest floor were taken back to the lab for cleaning and dissection. Root tips were sorted morphologically under a dissecting microscope. Clean internal sporocarp tissue or hydrogen peroxide sterilized EMF root tip samples were transferred using sterile technique to Petri plates with Modified Melin Norkrans (MMN) agar (Marx 1969) containing benomyl fungicide and antibiotics. Voucher specimens of sporocarps were established at the time of collection and are stored at the USDA Forest Service Northern Research Station, Houghton, MI, USA. After growth was established on the MMN agar or liquid, 125 sporocarp and root tip cultures were selected in accordance to their successful growth and site location (low, intermediate, and high) over the $\mathrm{N}$ gradient. Identification of the 125 isolates was confirmed using molecular genetic sequencing following the methods of Andrew (2009) (Luokkala, unpublished data). 


\section{Experimental isolate preparation}

The cultures were stored at $15^{\circ} \mathrm{C}$ on $\mathrm{MMN}$ agar or MMN liquid while fast growing cultures such as Paxillus involutus were stored as 5-mm-diameter plugs in sterile distilled deionized water $\left(\mathrm{ddH}_{2} \mathrm{O}\right)$ and slow growing cultures such as Piloderma spp. were placed in citrate buffer solution for approximately one year at the US Forest Service Northern Research Station Forestry Sciences Laboratory, Houghton, MI, USA (Table 3). The cultures selected for this experiment (Table 3) were removed from storage and checked for viability by transferring them into fresh MMN media for approximately six months (some faster growing isolates were transferred several times). Once viability was confirmed, residual agar was carefully removed from the experimental isolates and they were placed in jars of induction medium where their tissue was broken up with a sterile immersion blender allowing for a homogenous hyphal distribution in solution (Appendix 1). The basal induction medium was 10\% strength MMN (Kottke et al. 1987) excluding malt extract and ammonium phosphate. Ammonium chloride $\left(\mathrm{NH}_{4} \mathrm{Cl}\right)$ replaced the ammonium phosphate nitrogen source $(\mathrm{N}: \mathrm{P}=10)$, citrate buffer was added to maintain the medium at $\mathrm{pH} 4.8$, and glucose was added as the sole carbon source (Appendix 1, 4, and 5). The isolates remained in the induction medium for approximately two months in static culture at $15^{\circ} \mathrm{C}$.

\section{Pure culture $N$ and $P$ experiment}

The experimental cultures were grown in test tubes without $\mathrm{N}$ (minus- $\mathrm{N}$ control), with ammonium chloride $\left(\mathrm{NH}_{4} \mathrm{Cl}\right)$ for the inorganic $\mathrm{N}$ treatment, with essentially globulin and protease free albumin from bovine serum (BSA, \#A3059 SigmaAldrich Co., St. Louis, MO, USA) for the organic N treatment, without P for the minus-P control, with potassium phosphate $\left(\mathrm{KH}_{2} \mathrm{PO}_{4}\right)$ for the inorganic $\mathrm{P}$ treatment, and with phytic acid dipotassium salt $\left(\mathrm{C}_{6} \mathrm{H}_{16} \mathrm{~K}_{2} \mathrm{O}_{24} \mathrm{P}_{6}\right.$, \#P5681 Sigma-Aldrich Co., St. Louis, MO, USA) for the organic $\mathrm{P}$ treatment. For organic $\mathrm{N}$ and $\mathrm{P}$ assays, the basal medium for the experiment was MMN excluding malt extract with glucose added at $5 \mathrm{~g} / \mathrm{L}$ serving as the carbon source (Appendices 2-4). The citrate buffer was again used across all treatments to maintain $\mathrm{pH}$ at 4.8 . 
Bovine serum albumin, representing a large group of water soluble proteins found in plants and animals, is an omnipresent proteinaceous nitrogen source used in mycorrhizal fungal proteinase incubation experiments (Abuzinadah and Read 1986, Leake and Read 1991). The phytic acid dipostassium salt was qualitatively assayed to confirm its purity in Dr. Pushpalatha Murthy's chemistry lab, Michigan Technological University, Houghton, MI, USA. The BSA and phytic acid were filter sterilized before each one was added to the autoclaved basal medium.

Each inoculum was equally pipetted at $1 \mathrm{~mL}$ from the induction jars into their respective test tubes $(\mathrm{n}=3)$. There were three harvest dates for each treatment with three replications on each harvest date. All initial harvest dates were conducted on day 24 or 25 after inoculation. Cultures were harvested, vacuum filtered, freeze dried, and fungal biomass was measured on a microbalance (Mettler-Toledo XP56). The second and third harvest dates were executed according to visible fungal growth rates in an attempt to capture a representative growth rate according to the fungal response to each of the treatments. See Appendix 5 for detailed experimental protocol.

\section{Statistical design and analysis}

The study tested fungal growth in response to inorganic and organic $\mathrm{N}$ and $\mathrm{P}$ nutrient treatments relative to minus- $\mathrm{N}$ and minus-P controls. The overall study independent variables were the fungal species, strains of fungal isolates within species, the site of isolate origin (low, intermediate, and high $\mathrm{N}$ ), the $\mathrm{N}$ and $\mathrm{P}$ nutrient treatments (inorganic, organic, and control), and time (1, 2, and 3 harvests). Some species were not found at all sites. A harvest of each inoculum at each harvest prevented a repeated measures approach. The dependent variable was fungal biomass.

This report only tested the independent variables $\mathrm{N}$ and $\mathrm{P}$ nutrient treatments (inorganic, organic, and control) and the variable time (1, 2, and 3 harvests). The fungal growth in the $\mathrm{N}$ treatments relative to minus- $\mathrm{N}$ controls and in the $\mathrm{P}$ treatments relative to the minus-P controls were tested using one-way ANOVAs. A Dunnett's post hoc comparison test was utilized to compare mean treatment affects relative to control at $p$ 
values at 0.05, 0.01, and 0.001 (Zar 1999). All statistical tests were done in Minitab 15 (Minitab Inc. 2012).

\section{Results}

Nitrogen utilization

All of the ECM species analyzed in this report had significant growth on inorganic $\mathrm{N}(p<0.05)$, while selected isolates of four species ( $P$. involutus, $P$. byssinum, $P$. fallax, and L. bicolor) from across the $\mathrm{N}$ gradient significantly responded to organic $\mathrm{N}$ $(p<0.05)$ (Tables 4 and 8). Paxillus involutus isolate 07-29B, $P$. byssinum isolate 749, and $A$. byssoides isolate 873 did not display a significant growth response in the inorganic and organic $\mathrm{N}$ treatments $(p>0.05)$ (Figure 7 and Table 4). Consistent with our hypothesis, two low affinity $\mathrm{N}$ taxa ( $P$. byssinum and $P$. fallax) displayed significant growth on protein (Figures 14 and 16 and Table 4). However, two high affinity $\mathrm{N}$ taxa (L. bicolor and P. involutus) also grew on the protein (Figures 4 and 5 and Table 4). High affinity taxon $P$. involutus isolates and low affinity $\mathrm{N}$ taxon $P$. fallax isolates showed significant intraspecific variation in response to the organic $\mathrm{N}$ treatment $(p<$ 0.05) (Figures 4, 6, 8, 9, and 13-15 and Table 4).

Growth patterns varied over the harvest dates for some isolates. Laccaria bicolor significantly responded to both inorganic and organic $\mathrm{N}$ treatments $(p<0.0001$ for both treatments at the second and third harvests). While its growth on organic $\mathrm{N}$ lagged behind the growth on inorganic $\mathrm{N}$ by $18.26 \pm 1.60 \mathrm{mg}$ (mean $\pm 1 \mathrm{SE}$ ) at the second harvest, growth drastically slowed down on inorganic $N$ at the third harvest by $0.80 \pm$ 1.82 mg displaying growth on organic $\mathrm{N}$ was similar to the biomass on inorganic $\mathrm{N}$ (Figure 5 and Table 4). Piloderma byssinum isolate 287 displayed a similar growth trajectory in both inorganic and organic $\mathrm{N}$ treatments $(p<0.05)$ (Figure 16 and Table 4$)$. In contrast, $P$. involutus isolate 06-38 displayed significant growth on organic $\mathrm{N}$ that lagged behind the growth on inorganic $\mathrm{N}$ in relation to the control by $19.14 \pm 1.08 \mathrm{mg}$ at the third harvest $(p<0.05)$ (Figure 4 and Table 4$)$. Although the two treatments were insignificant relative to the control, $P$. involutus isolate 07-29B displayed a growth trend 
on organic $\mathrm{N}$ that lagged behind the growth on inorganic $\mathrm{N}$ by $11.91 \pm 8.29 \mathrm{mg}$ at the second harvest and only lagged behind by $6.21 \pm 11.94 \mathrm{mg}$ at the third harvest date (Figure 7 and Table 4).

\section{Phosphorus utilization}

At least one isolate of each of the ECM species except $P$. byssinum grew significantly on inorganic $\mathrm{P}(p<0.05)$ (Tables 5 and 8). Fewer isolates responded positively to the organic $\mathrm{P}$ treatment (Tables 5 and 8). Low affinity $\mathrm{N}$ taxon $P$. fallax isolate 18 and the high affinity $\mathrm{N}$ taxon $P$. involutus isolate 862 only significantly grew on inorganic P in respect to the control (Figures 10 and 15 and Table 5).

Isolates from the $\mathrm{P}$ treatments in which three harvest dates were analyzed in this report displayed intraspecific and interspecific variation in growth patterns. One distinctive pattern was in high $\mathrm{N}$ affinity isolates $P$. involutus isolates 06-38 and 07-20D and Atheliaceae 1 642. They displayed a growth pattern in which the growth rate on inorganic $\mathrm{P}$ was faster, the organic $\mathrm{P}$ uptake was more gradual, and the biomass accumulation was significantly higher in the organic P treatment at the third harvest date $(p<0.05)$ (Figures 3, 4, and 6 and Table 5). This growth trend was also noted in two low $\mathrm{N}$ affinity isolates $P$. fallax 16 and $A$. byssoides 873 both from low $\mathrm{N}$ sites (Figures 14 and 20). In contrast, high $\mathrm{N}$ affinity isolates $P$. involutus 07-29B displayed an opposite growth pattern in which the growth rate on organic $\mathrm{P}$ was higher, the inorganic $\mathrm{P}$ uptake was more gradual, and the biomass accumulation was higher in the inorganic P treatment at the third harvest date (Figures 12 and Table 5).

\section{Discussion}

\section{Nitrogen utilization}

The first hypothesis expecting taxa from low $\mathrm{N}$ soils to utilize organic $\mathrm{N}$ more efficiently than taxa from high $\mathrm{N}$ soils was not supported by all of the isolates from across the gradient. Additionally, one isolate from an intermediate $\mathrm{N}$ site (L. bicolor) and another isolate from a high $\mathrm{N}$ site ( $P$. involutus) grew on protein, which reduces the 
supposition that taxa from low $\mathrm{N}$ sites would show a greater capability in producing proteases for the uptake of organic nitrogen sources. However, ECM have displayed reduced protein $\mathrm{N}$ uptake under higher $\mathrm{N}$ deposition (Lilleskov et al. 2002b, Taylor et al. 2000). Our results showed two (P. byssinum and $P$. fallax) out of the five species from low $\mathrm{N}$ sites responded to the organic $\mathrm{N}$ treatment (A. byssoides, $H$. speciosus, and $P$. involutus did not respond), while only $22 \%$ of the total isolates from the low $\mathrm{N}$ sites responded to the organic $\mathrm{N}$ treatment indicating intraspecific variation.

Interestingly, low and high affinity $\mathrm{N}$ taxa both responded to the protein treatments in a similar manner showing there is greater interspecific variability than the hypothesis took into account. It appeared as though the isolates L. bicolor 06-64.1, P. involutus 07-20D, and P. involutus 07-29B displayed a lag growth and eventually acclimatized to the treatments to actively produce protease enzymes to take up organic nitrogen, while other species such as $A$. byssoides, $P$. fallax, $P$. byssinum, and $H$. speciosus were able to grow on both inorganic and organic $\mathrm{N}$ nutrients without a delayed response time. Interestingly, accumulated research shows the genus Laccaria has proven to be defined as a nonuser of protein N (Lilleskov 2011), but this analysis has found it has significantly responded to organic N. It is important to point out that $L$. bicolor's growth on protein $\mathrm{N}$ substrate showed up only after 50 days of incubation (Figure 5 and Table 4).

The data has also shown intraspecific variability in response to nitrogen amongst the $P$. involutus, $A$. byssoides, and $P$. fallax isolates which the hypothesis does not take into account. Paxillus have shown to be variable protein users while Piloderma have been cited as protein users (Lilleskov 2011). However, the results in this study place $P$. fallax as a variable user. This analysis has also found that previously undefined Amphinema and Hygrophorus as potential protein users. One of the variables that should be considered is the amount of time cultures are allowed to grow.

\section{Phosphorus utilization}

The data did not fully support the second hypothesis regarding taxa from high $\mathrm{N}$ sites should be expected to use organic P sources compared to the ECM dominant in low $\mathrm{N}$ soils, because there was not a difference in the overall species response to inorganic 
and organic phosphorus nutrient treatments. However, this data set ascertains many and/or most ECM are capable of inositol hexaphosphate breakdown and subsequent uptake.

Even though all of the isolates analyzed in this report positively responded to the organic P treatment, it is important to point out that the isolate site location might play a role in the distinctive and contrasting growth rate patterns. The isolates that displayed an initial higher growth rate on organic $\mathrm{P}$ were from the high $\mathrm{N}$ site while the isolates that displayed a lagged growth response to organic $\mathrm{P}$ while quickly growing on inorganic $\mathrm{P}$ were from the low $\mathrm{N}$ sites. This could indicate intraspecific variability amongst the isolates from high $\mathrm{N}$ sites requiring less time to be induced into producing phosphatase enzymes for organic P uptake compared to the isolates from low $\mathrm{N}$ sites.

\section{Conclusion}

In conclusion, the resulting data for both $\mathrm{N}$ and $\mathrm{P}$ treatments displays a mixture of support, refutation, and mixed results in respect to the hypotheses. High affinity $\mathrm{N}$ taxa expected to respond positively to inorganic $\mathrm{N}$ produced the phosphatase enzyme to take up organic phosphorus, but not all low affinity $\mathrm{N}$ taxa expected to negatively respond to organic $\mathrm{P}$ produced the protease enzyme to take up organic N. Interestingly, some high and low affinity $\mathrm{N}$ taxa responded in nearly an identical manner to some of the $\mathrm{N}$ and $\mathrm{P}$ treatments signifying interspecific variability. Lastly, this analysis has also shown ECM intraspecific variability in response to $\mathrm{N}$ and $\mathrm{P}$ treatments. Future analysis of the remaining data may show more evident ECM response patterns to the inorganic and organic forms of $\mathrm{N}$ and $\mathrm{P}$. 


\section{Acknowledgements}

Funding for this project was provided by an USDA CSREES grant and the USDA Forest Service Northern Research Station. Special thanks to Carrie Andrew, Caly Bodeis, Michael Candler, Sam Coleman, Margaret Gale, Ruth Gleckler, John Hribljan, Steven Johnson, Pushpalatha Murphy, Andrew Quinn, Dana Richter, and Linda van Diepen for their help with the project. 


\section{References}

Abuzinadah R.A. and D.J. Read. 1986. The role of proteins in the nitrogen nutrition of ectomycorrhizal plants. III. Protein utilization by Betula, Picea, and Pinus in mycorrhizal association with Hebeloma crustuliniforme. New Phytologist 103: 507-514.

Andrew, C. J. 2009. Response of ectomycorrhizal fungi to elevated atmospheric carbon dioxide and ozone within northern deciduous forests.

Brady, N. C. and R. R. Weil. 1996. The nature and properties of soils. Prentice-Hall Inc.

Cairney, J. 1999. Intraspecific physiological variation: implications for understanding functional diversity in ectomycorrhizal fungi. Mycorrhiza 9:125-135.

Chalot, M. and A. Brun. 1998. Physiology of organic nitrogen acquisition by ectomycorrhizal fungi and ectomycorrhizas. Microbiology Reviews 22: 21-44.

Chalot, M. and A. Brun. 2006. Physiology of organic nitrogen acquisition by ectomycorrhizal fungi and ectomycorrhizas. FEMS microbiology reviews 22:2144.

Chalot, M., A. Javelle, D. Blaudez, R. Lambilliote, R. Cooke, H. Sentenac, D. Wipf, and B. Botton. 2002. An update on nutrient transport processes in ectomycorrhizas. Plant and soil 244:165-175.

Chalot, M., M. Kytöviita, A. Brun, R. Finlay, and B. Söderström. 1995. Factors affecting amino acid uptake by the ectomycorrhizal fungus Paxillus involutus. Mycological research 99:1131-1138.

Colpaert, J.V., A. van Laere, K.K. van Tichelen, and J.A. van Assche. 1997. The use of inositol hexaphosphate as a phosphorus source by mycorrhizal and nonmycorrhizal Scots Pine (Pine sylvestris). Functional Ecology 11: 407-415.

Conn, C. and J. Dighton. 2000. Litter quality influences on decomposition, ectomycorrhizal community structure and mycorrhizal root surface acid phosphatase activity. Soil Biology and Biochemistry 32:489-496.

Cumming, J.R. 1993. Growth and nutrition of nonmycorrhizal and mycorrhizal pitch pine (Pinus rigida) seedlings under phosphorus limitation. Tree Physiology 13:173187.

Finlay, R. D. \& B. Söderström. 1992. Mycorrhiza and Carbon Flow to Soil. In: M. F. 
Allen, ed. Mycorrhizal Functioning, pp.134-160.Chapman \& Hall, London.

Gebauer, G. and A. Taylor. 1999. 15N natural abundance in fruit bodies of different functional groups of fungi in relation to substrate utilization. New Phytologist 142:93-101.

Hayes, J. E., R. J. Simpson, and A. E. Richardson. 2000. The growth and phosphorus utilisation of plants in sterile media when supplied with inositol hexaphosphate, glucose 1-phosphate or inorganic phosphate. Plant and Soil 220:165-174.

Heinonen-Tanski, H. and T. Holopainen. 1991. Maintenance of Ectomycorrhizal Fungi. Methods in microbiology 23:413-422.

Hobbie, E. A. 2006. Carbon allocation to ectomycorrhizal fungi correlates with belowground allocation in culture studies. Ecology 87:563-569.

Jansa, J., R. Finlay, H. Wallander, F. A. Smith, and S. E. Smith. 2011. Role of mycorrhizal symbioses in phosphorus cycling. Phosphorus in Action:137-168.

Jentschke, G., B. Brandes, A. J. Kuhn, W. H. Schröder, and D. L. Godbold. 2001. Interdependence of phosphorus, nitrogen, potassium and magnesium translocation by the ectomycorrhizal fungus Paxillus involutus. New Phytologist 149:327-337.

Kottke, I., M. Guttenberger, R. Hampp, and F. Oberwinkler. 1987. An in vitro method for establishing mycorrhizae on coniferous tree seedlings. Trees-Structure and Function 1:191-194.

Leake J.R. and D.J. Read. 1991. Proteinase activity in mycorrhizal fungi III. Effects of protein, protein hydrolysate, glucose and ammonium on production of extracellular proteinase by Hymenoscyphus ericae (Read) Korf \& Kernan. New Phytologist 117: 309-317.

Lilleskov, E., T. Fahey, and G. Lovett. 2001. Ectomycorrhizal fungal aboveground community change over an atmospheric nitrogen deposition gradient. Ecological Applications 11:397-410.

Lilleskov, E., E. Hobbie, and T. Horton. 2011. Conservation of ectomycorrhizal fungi: exploring the linkages between functional and taxonomic responses to anthropogenic N deposition. Fungal Ecology 4:174-183.

Lilleskov, E. A., T. J. Fahey, T. R. Horton, and G. M. Lovett. 2002a. Belowground ectomycorrhizal fungal community change over a nitrogen deposition gradient in Alaska. Ecology 83:104-115. 
Lilleskov, E. A., E. A. Hobbie, and T. J. Fahey. 2002b. Ectomycorrhizal fungal taxa differing in response to nitrogen deposition also differ in pure culture organic nitrogen use and natural abundance of nitrogen isotopes. New Phytologist 154:219-231.

Marschner, H. and B. Dell. 1994. Nutrient uptake in mycorrhizal symbiosis. Plant and soil 159:89-102.

Marx, D. H. 1969. The influence of ectotrophic mycorrhizal fungi on the resistance of pine roots to pathogenic infections. I. Antagonism of mycorrhizal fungi to root pathogenic fungi and soil bacteria. Phytopathology 59:153-163.

Nehls, U., M. Ecke, and R. Hampp. 1999. Sugar-and nitrogen-dependent regulation of an Amanita muscaria phenylalanine ammonium lyase gene. Journal of Bacteriology 181:1931-1933.

Nygren, C. M. R., J. Edqvist, M. Elfstrand, G. Heller, and A. F. S. Taylor. 2007. Detection of extracellular protease activity in different species and genera of ectomycorrhizal fungi. Mycorrhiza 17:241-248.

Pacheco, S., J. Cambraia, and M. Kasuya. 1991. Effect of different levels of P on acid phosphatase activity and mineral composition of some ectomycorrhizal fungi. Revista de Microbiologia 22:345-348.

Pritsch, K., S. Raidl, E. Marksteiner, H. Blaschke, R. Agerer, M. Schloter, and A. Hartmann. 2004. A rapid and highly sensitive method for measuring enzyme activities in single mycorrhizal tips using 4-methylumbelliferone-labelled fluorogenic substrates in a microplate system. Journal of microbiological methods 58:233-241.

Rangel-Castro, I. J., E. Danell, and A. F. Taylor. 2002. Use of different nitrogen sources by the edible ectomycorrhizal mushroom Cantharellus cibarius. Mycorrhiza 12:131-137.

Read, D. and J. Perez-Moreno. 2003. Mycorrhizas and nutrient cycling in ecosystems-a journey towards relevance? New Phytologist 157:475-492.

Read, D. J. 1991. Mycorrhizas in ecosystems. Cellular and Molecular Life Sciences 47:376-391.

Richter, D. L. and J. N. Bruhn. 1989. Revival of saprotrophic and mycorrhizal basidiomycete cultures from cold storage in sterile water. Canadian journal of microbiology 35:1055-1060. 
Richter, D. L. R. D. L. 2008. Revival of saprotrophic and mycorrhizal basidiomycete cultures after 20 years in cold storage in sterile water. Canadian journal of microbiology 54:595-599.

Rygiewicz, P. T. and J. L. Armstrong. 1991. RFLPs and Probe Hybridization. Techniques for the Study of Mycorrhiza 23:253.

Sinsabaugh, R. L. and A. E. Linkins. 1993. Statistical modeling of litter decomposition from integrated cellulase activity. Ecology:1594-1597.

Smith, D. and A. Onions. 1994. The preservation and maintenance of living fungi. The preservation and maintenance of living fungi.

Smith, S. E. and D. J. Read. 2008. Mycorrhizal symbiosis. Academic Press.

Taylor, A., F. Martin, and D. Read. 2000. 16 Fungal Diversity in Ectomycorrhizal Communities of Norway Spruce [Picea abies (L.) Karst.] and Beech (Fagus sylvatica L.) Along North-South Transects in Europe. Carbon and nitrogen cycling in European forest ecosystems 142:343.

Treseder, K. K. 2004. A meta-analysis of mycorrhizal responses to nitrogen, phosphorus, and atmospheric CO2 in field studies. New Phytologist 164:347-355.

Turner, B. L., M. J. Papházy, P. M. Haygarth, and I. D. McKelvie. 2002. Inositol phosphates in the environment. Philosophical Transactions of the Royal Society of London. Series B: Biological Sciences 357:449-469.

Wallenda, T. and D. Read. 2002. Kinetics of amino acid uptake by ectomycorrhizal roots. Plant, Cell \& Environment 22:179-187.

Zar J.H. 1999. Biostatistical Analysis. Prentice Hall.

Zhu, H., B. P. Dancik, and K. O. Higginbotham. 1994. Regulation of extracellular proteinase production in an ectomycorrhizal fungus Hebeloma crustuliniforme. Mycologia:227-234. 


\section{Tables}

Table 1

The documented ectomycorrhizal fungal response to elevated nitrogen of the taxa analyzed in this report (Lilleskov et al. 2011).

\begin{tabular}{cc}
\hline Low & High \\
\hline Amphinema & Atheliaceae 1 \\
Hygrophorus & Laccaria \\
Thelephora & Paxillus \\
& Piloderma \\
\hline
\end{tabular}


Table 2

Ectomycorrhizal fungal growth response to protein (Lilleskov et al. 2011).

\begin{tabular}{llll}
\hline Nonprotein Users & $\begin{array}{l}\text { Variable Protein } \\
\text { Users }\end{array}$ & Protein Users & No Data \\
\hline Laccaria & Cenococcum & Cortinarius spp. & Amphinema \\
& Lactarius & Piloderma & Hygrophorus \\
& Paxillus & Russula & Pseudotomentella \\
& Thelephora & Tricholoma & Tomentella \\
& Tylospora & & \\
\hline
\end{tabular}


Table 3

Fungal species used in the study with details of their isolation from $\mathrm{N}$ deposition site origin. The taxa in bold were analyzed in this report for growth response on inorganic and organic nitrogen and phosphorus nutrient treatments.

\begin{tabular}{|c|c|c|c|}
\hline Experimental Species & Low N & Intermediate $\mathrm{N}$ & High $N$ \\
\hline Atheliaceae 1 Jülich & $\mathbf{X}$ & $\mathbf{x}$ & $\mathbf{X}$ \\
\hline Amphinema byssoides (Pers.:Fr.) Erikss. & $\mathbf{x}$ & $\mathbf{x}$ & $\mathbf{x}$ \\
\hline Cortinarius sp. (Pers.) Gray & $\mathrm{x}$ & & $\mathrm{x}$ \\
\hline Cenococcum geophilum Fr. & $\mathrm{X}$ & & \\
\hline Hygrophorus pustulatus (Pers. Ex Fr.) Fr. & $\mathrm{x}$ & & \\
\hline Hygrophorus speciosus $\mathbf{P k}$. & $\mathbf{x}$ & & \\
\hline Laccaria bicolor (Maire) Orton & & $\mathbf{x}$ & $\mathbf{x}$ \\
\hline $\begin{array}{l}\text { Lactarius olivaceoumbrinus Smith } \\
\text { Lactarius tabidus Fr. }\end{array}$ & & & $\mathrm{x}$ \\
\hline Lactarius theiogalus (Bull Fr.) S.F. Gray & $\mathrm{x}$ & $X$ & $\mathrm{x}$ \\
\hline Paxillus involutus (Batsch : Fr.) Fr. & $\mathbf{x}$ & $\mathbf{x}$ & $\mathbf{x}$ \\
\hline Piloderma byssinum (Karst.) Jülich & $\mathbf{x}$ & & \\
\hline Piloderma fallax (Libert) Stalpers & $\mathbf{x}$ & & \\
\hline Pseudotomentella sp. Svrcek & $\mathrm{x}$ & & \\
\hline Russula bicolor Burlingham & $\mathrm{x}$ & & \\
\hline Russula spp. Pers. & $\mathrm{x}$ & $\mathrm{x}$ & $\mathrm{x}$ \\
\hline Russula claroflava Grove & & & $\mathrm{x}$ \\
\hline Thelephora terrestris Fr. & & $\mathbf{x}$ & $\mathbf{x}$ \\
\hline Tomentella spp. Pers.ex Pat. & $\mathrm{X}$ & & \\
\hline Tomentella stuposa (Link) Stalpers & $\mathrm{x}$ & & \\
\hline Tomentella sublilacina (Ellis \& Holw.) & & & \\
\hline Wakef. & & $\mathrm{X}$ & $\mathrm{x}$ \\
\hline Tricholoma platyphyllum (Murrill) Sacc. & & & \\
\hline$\&$ Trotter & $\mathrm{X}$ & & \\
\hline Tricholoma inamoenum (Fr.:Fr.) Gill. & & & \\
\hline & $\mathrm{x}$ & & \\
\hline Tricholoma saponaceum (Fr.) Kummer & $\mathrm{x}$ & & \\
\hline Tylospora fibrillosa (Burt) Donk & & $X$ & \\
\hline
\end{tabular}




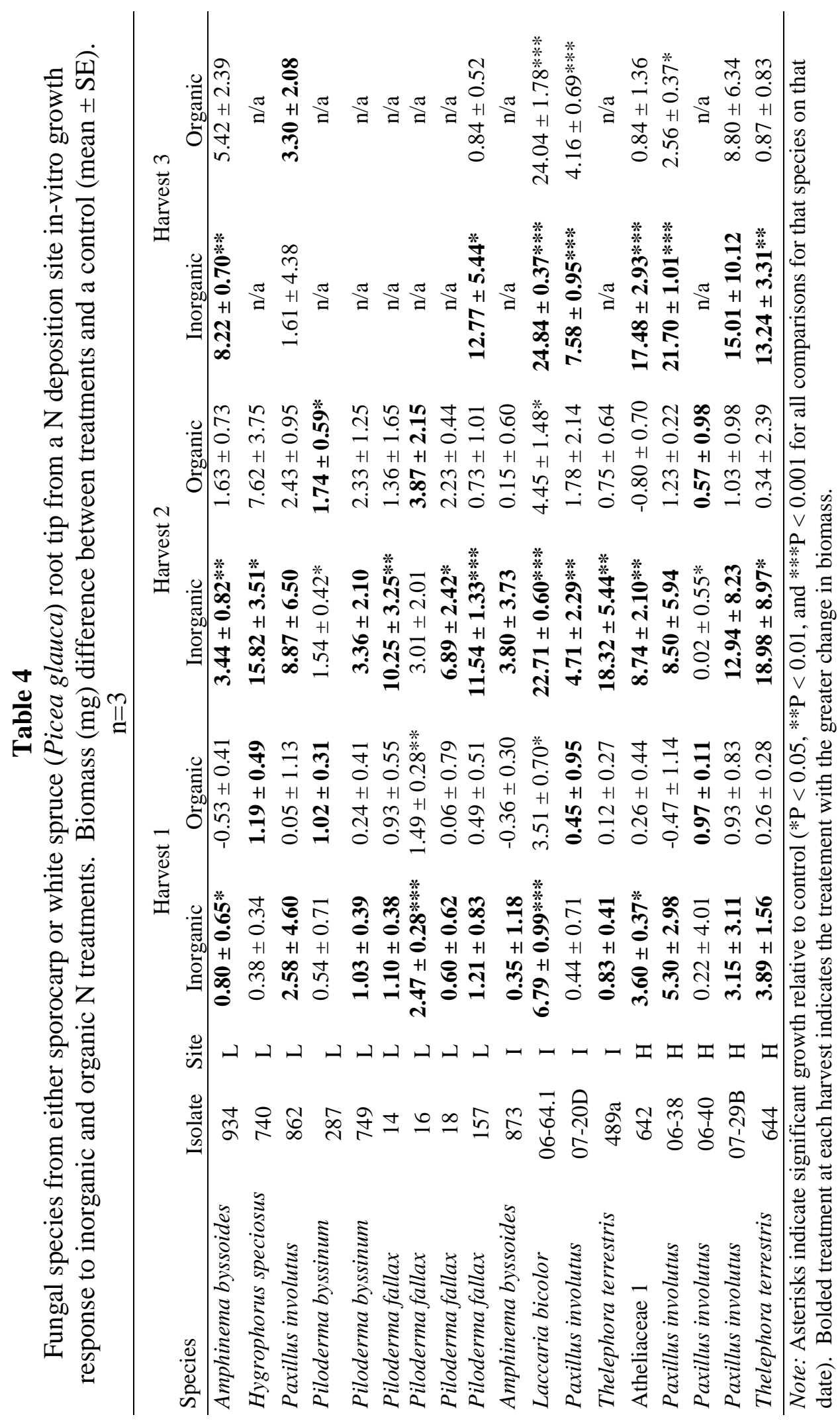




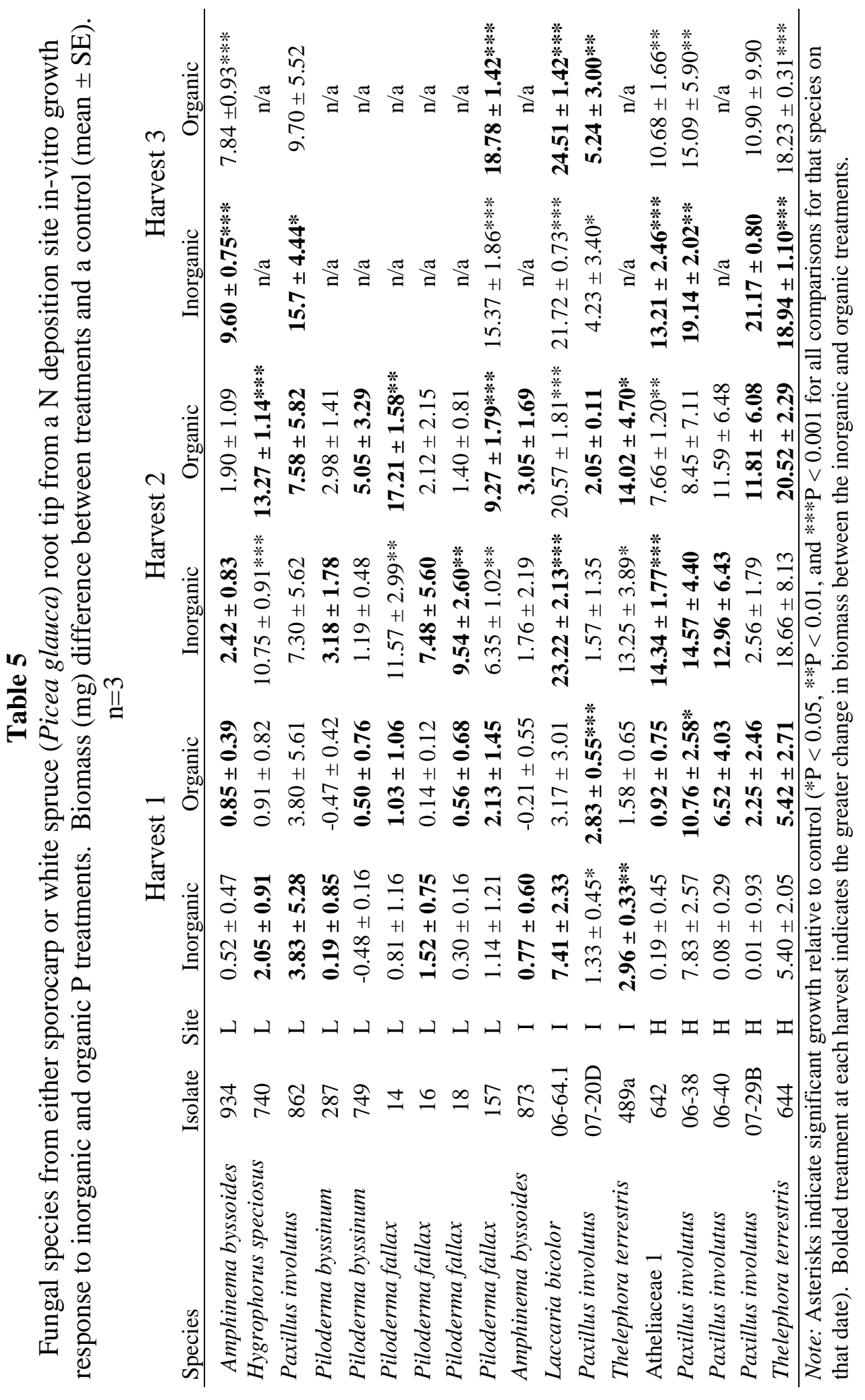




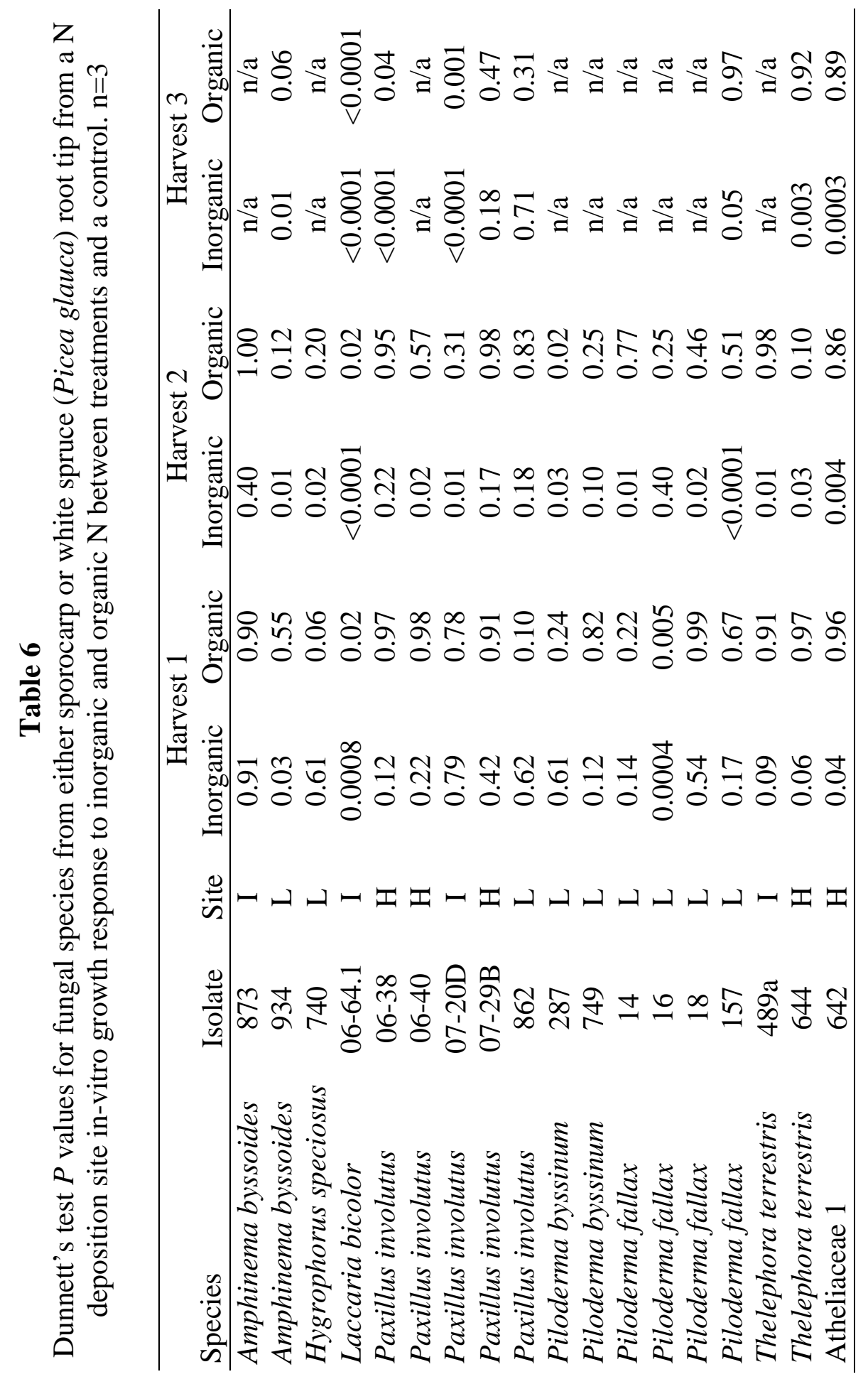




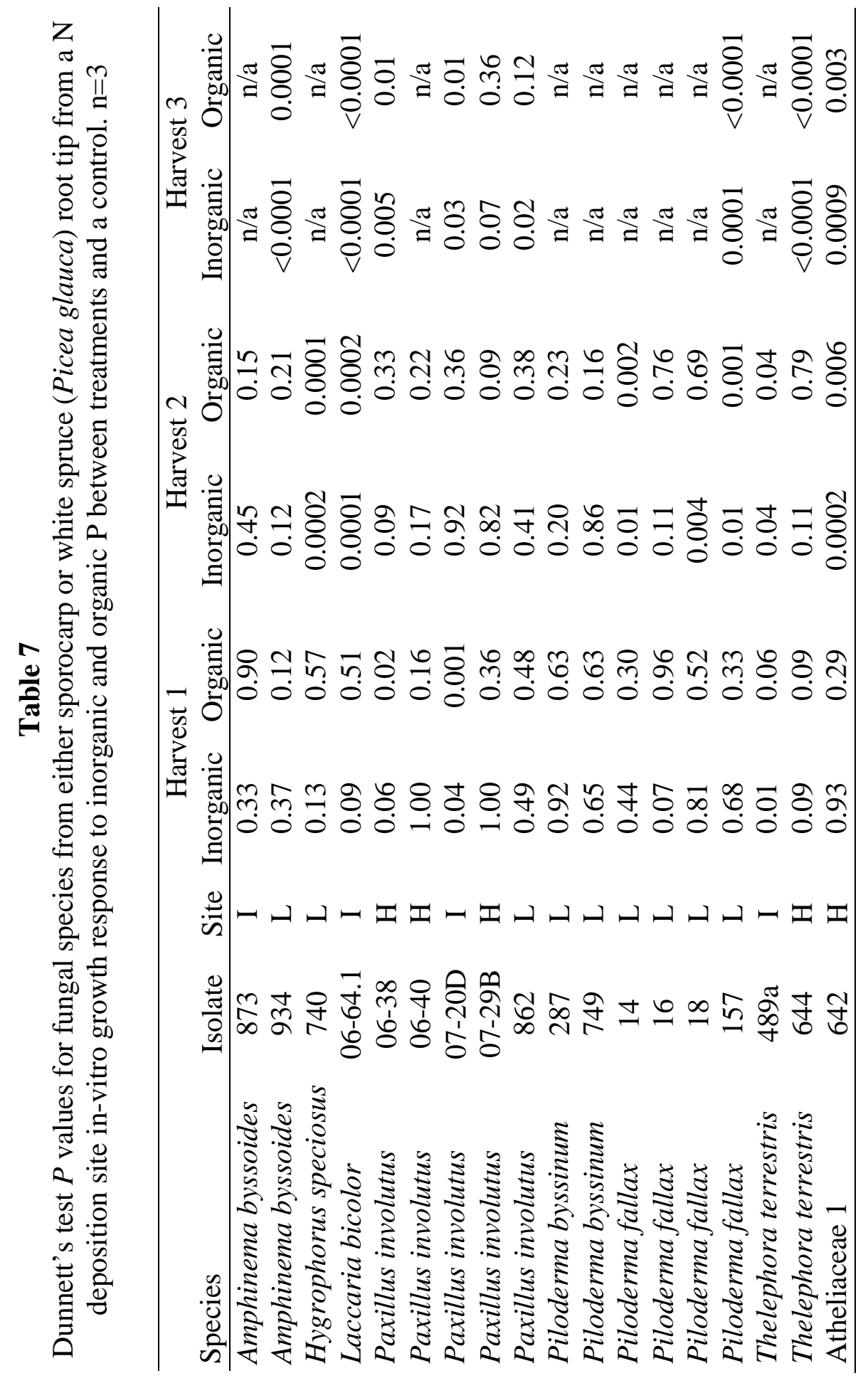




\section{Table 8}

A summary of the ectomycorrhizal significant growth response to inorganic and organic nitrogen and phosphorus in comparison to the controls $(p<0.05)$.

Species Isolate Site Inorganic N Organic N Inorganic $\mathrm{P}$ Organic $\mathrm{P}$

Amphinema byssoides 934

Hygrophorus speciosus 740

Paxillus involutus 862

Piloderma byssinum 287

Piloderma byssinum 749

Piloderma fallax $\quad 14$

Piloderma fallax $\quad 16$

Piloderma fallax $\quad 18$

Piloderma fallax $\quad 157$

Amphinema byssoides 873

Laccaria bicolor

06-64.1 I

Paxillus involutus

Thelephora terrestris

Atheliaceae 1

07-20D I

489a I

$642 \quad \mathrm{H}$

Paxillus involutus

06-38 H

06-40 H

$\mathrm{X}_{\mathrm{a}}$

$\mathrm{X}_{2}$

$\mathrm{X}_{2}$

$\mathrm{X}_{2}$

$\mathrm{X}_{1}$

$\mathrm{X}_{2}$

$\mathrm{X}_{2,3}$

$\mathrm{X}_{\mathrm{a}}$

$\mathrm{X}_{2}$

$\mathrm{X}_{2}$

$X_{\mathrm{a}}$

$\mathrm{X}_{3}$

$\mathrm{X}_{2}$

$\mathrm{X}_{2,3}$

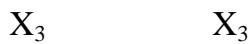

$\mathrm{X}_{2} \quad \mathrm{X}_{2}$

$\mathrm{X}_{3}$

$\mathrm{X}_{2}$

$\begin{array}{ll}\mathrm{X}_{2} & \mathrm{X}_{2}\end{array}$

$\mathrm{X}_{1}$

$\begin{array}{cc}\mathrm{X}_{2} & \\ \mathrm{X}_{2,3} & \mathrm{X}_{2,3}\end{array}$

$\begin{array}{lll}\mathrm{X}_{\mathrm{a}} & \mathrm{X}_{2,3} & \mathrm{X}_{2,3} \\ \mathrm{X}_{1,3} & \mathrm{X}_{1,3}\end{array}$

$\begin{array}{cc}\mathrm{X}_{1,3} & \mathrm{X}_{1,3} \\ \mathrm{X}_{1,2} & \mathrm{X}_{2}\end{array}$

$\begin{array}{ccc}\mathrm{X}_{3} & \mathrm{X}_{3} & \mathrm{X}_{1,3} \\ & & \end{array}$

$\begin{array}{lll}\text { Paxillus involutus } & 06-40 & \mathrm{H} \\ \text { Paxillus involutus } & 07-29 \mathrm{~B} & \mathrm{H}\end{array}$

Thelephora terrestris $644 \quad \mathrm{H}$

a indicates significance at harvest 1, 2, and 3; 1 indicates significance at harvest 1; 2 indicates significance at harvest 2; 3 indicates significance at harvest 3 


\section{Figures}

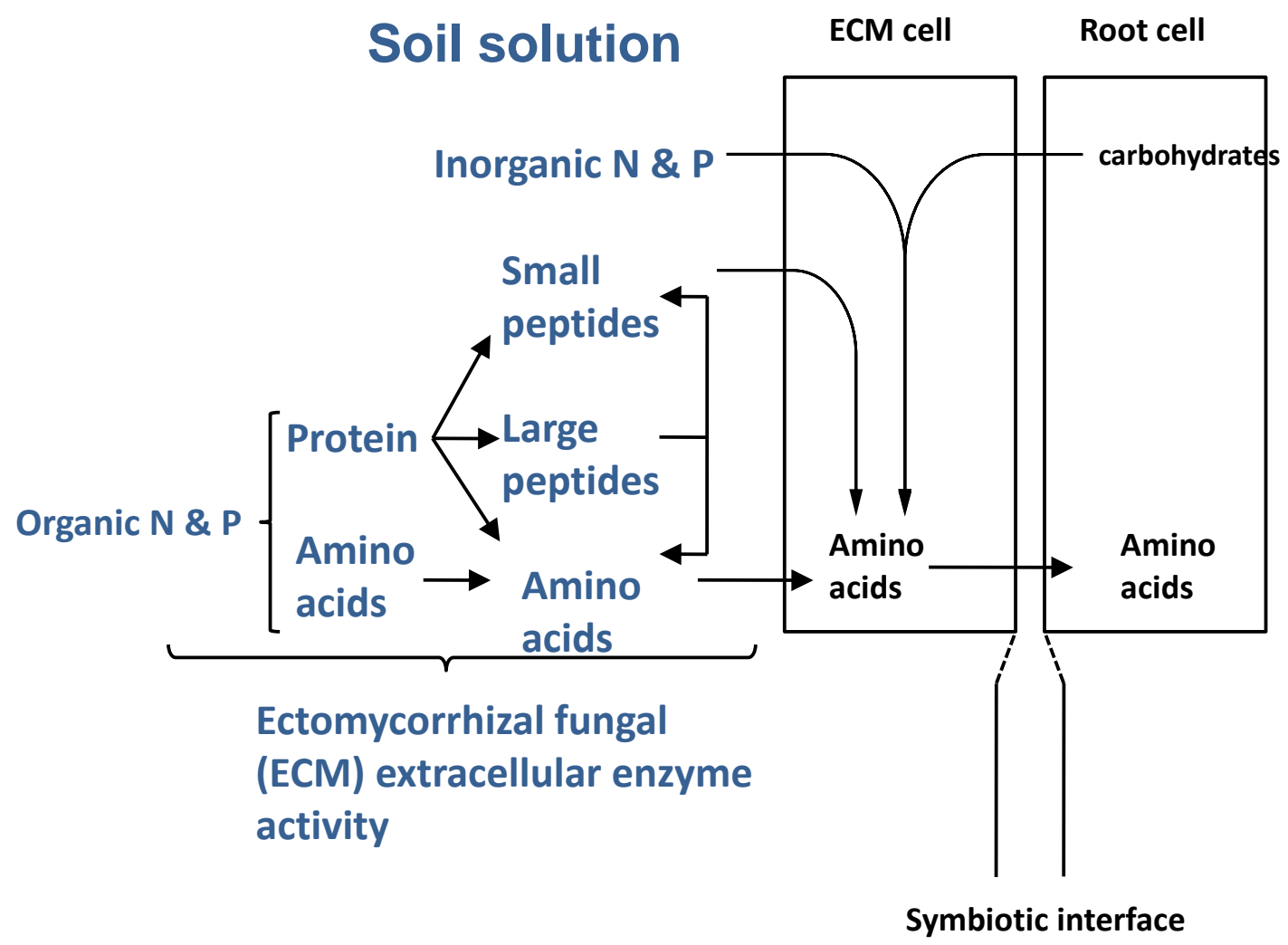

Figure 1 A model of the soil matrix, ectomycorrhizal fungal, and root interfaces (modified from Chalot and Brun 1998). Inorganic nitrogen and phosphorus are available for ectomycorrhizal fungi and plants to directly take up. Organic nitrogen and phosphorus bound in protein and amino acids are hydrolyzed by extracellular enzymes produced by ectomycorrhizal fungi which then take up the accessible nutrients. The nutrients taken up by the fungi are exchanged for carbohydrates from the plant root. 


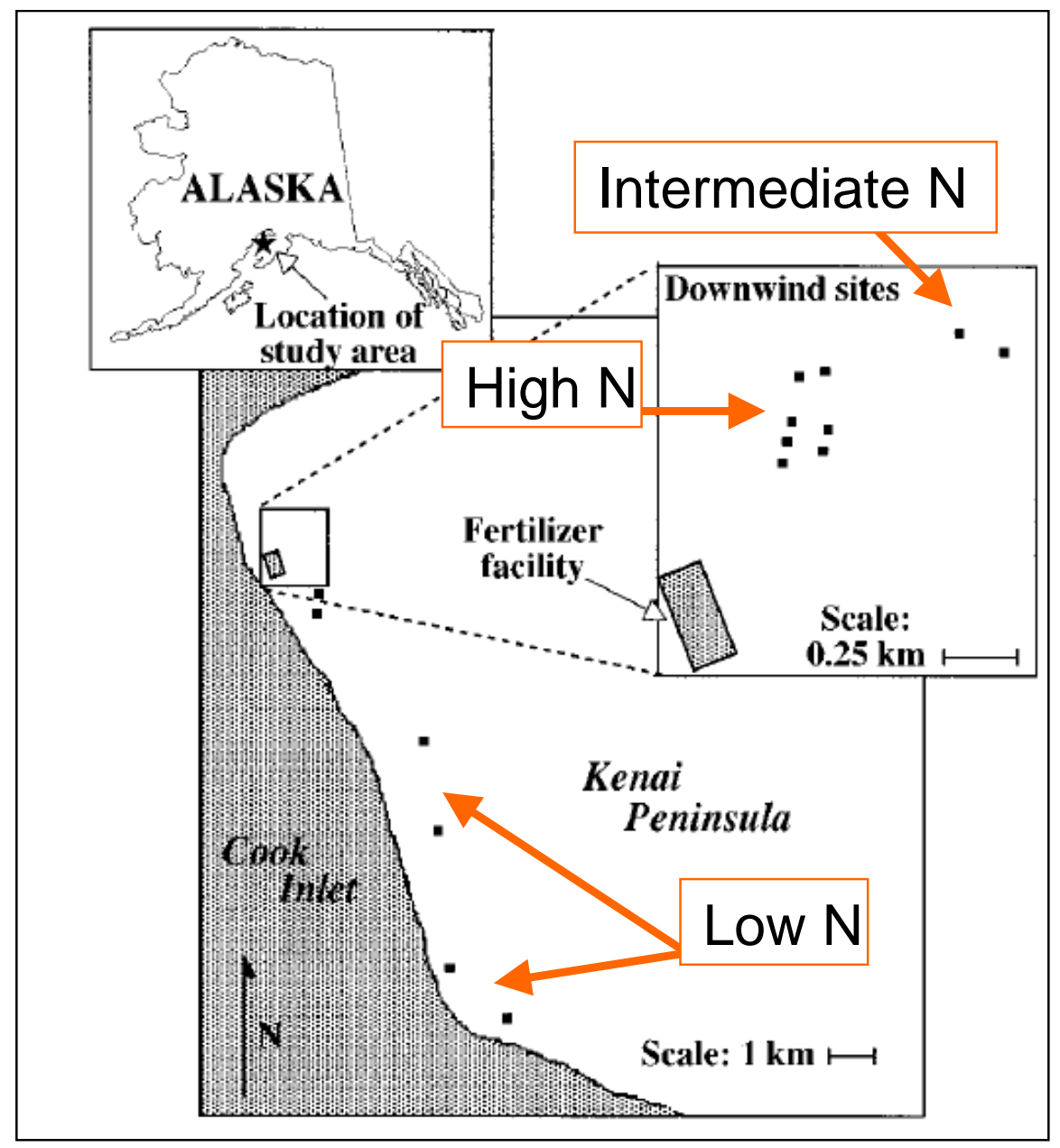

Figure 2 The study sites displaying defined low, intermediate, and high levels of N were located in a mature boreal forest on the Kenai Peninsula, in Alaska (modified from Lilleskov et al. 2001). An atmospheric ammonium deposition gradient exists near a fertilizer manufacturing facility with increased annual nitrogen deposition. 

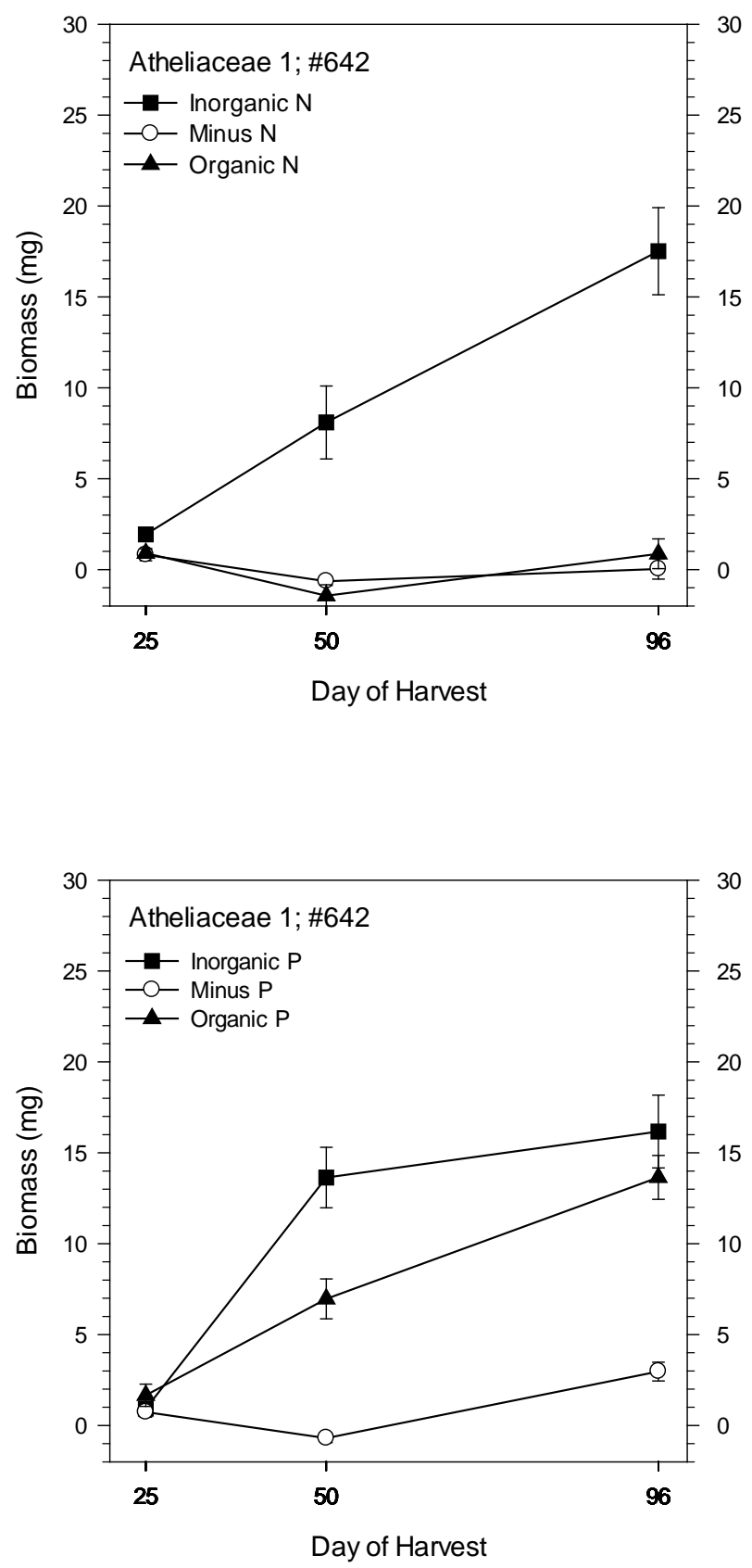

Figure 3 Pure culture growth rates (mean \pm SE) on three different $\mathrm{N}$ sources (top graph): minus $\mathrm{N}$ control (open circles), $\mathrm{NH}_{4} \mathrm{Cl}$ (closed squares), and bovine serum albumin (closed triangles); and on three different $\mathrm{P}$ sources (bottom graph): minus $\mathrm{P}$ control (open circles), $\mathrm{KH}_{2} \mathrm{PO}_{4}$ (closed squares), and phytic acid (closed triangles). $n=3$ 

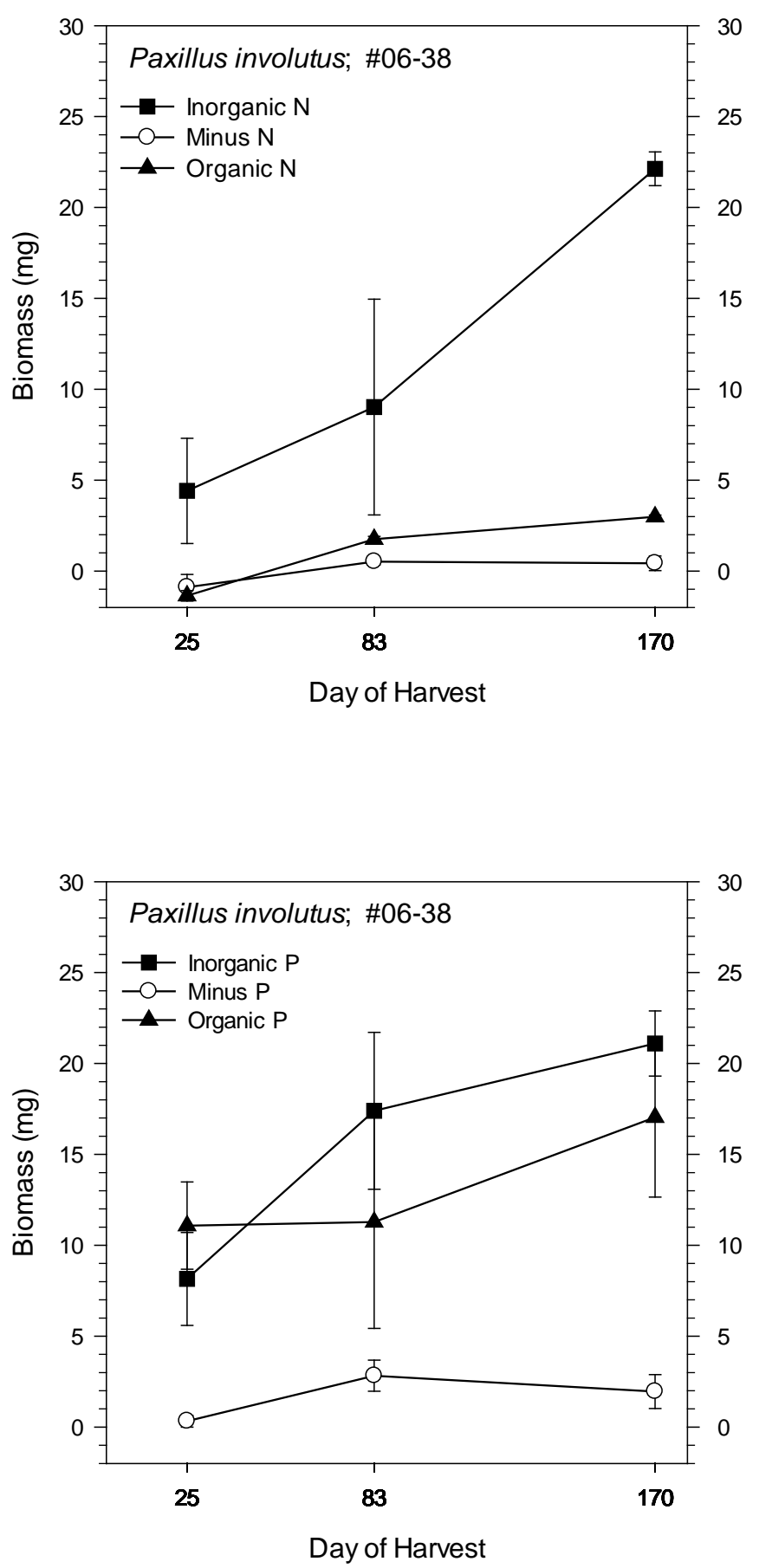

Figure 4 Pure culture growth rates (mean $\pm \mathrm{SE}$ ) on three different $\mathrm{N}$ sources (top graph): minus $\mathrm{N}$ control (open circles), $\mathrm{NH}_{4} \mathrm{Cl}$ (closed squares), and bovine serum albumin (closed triangles) and on three different $\mathrm{P}$ sources (bottom graph): minus $\mathrm{P}$ control (open circles), $\mathrm{KH}_{2} \mathrm{PO}_{4}$ (closed squares), and phytic acid (closed triangles). $\mathrm{n}=3$ 

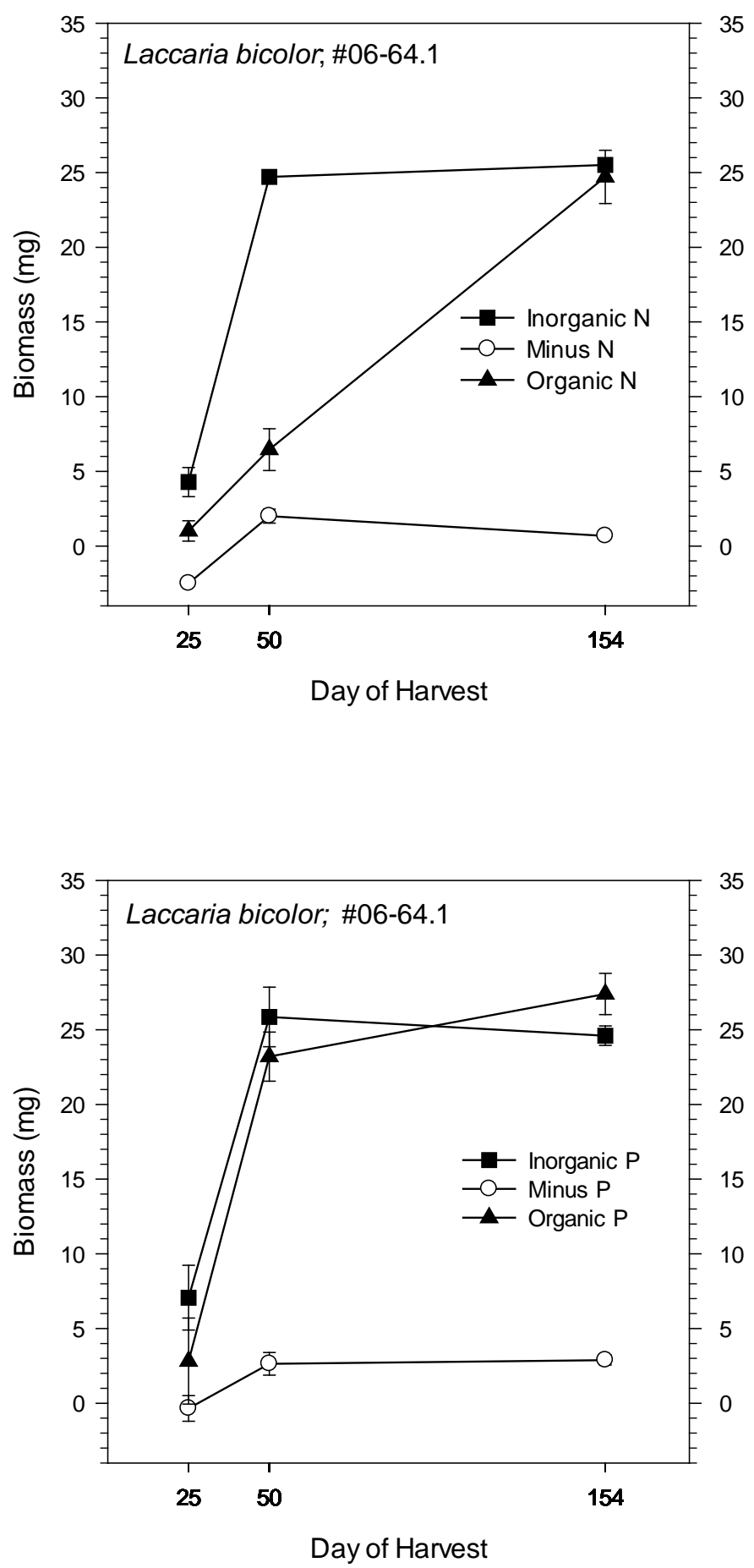

Figure 5 Pure culture growth rates (mean \pm SE) on three different $\mathrm{N}$ sources (top graph): minus $\mathrm{N}$ control (open circles), $\mathrm{NH}_{4} \mathrm{Cl}$ (closed squares), and bovine serum albumin (closed triangles) and on three different $\mathrm{P}$ sources (bottom graph): minus $\mathrm{P}$ control (open circles), $\mathrm{KH}_{2} \mathrm{PO}_{4}$ (closed squares), and phytic acid (closed triangles). $\mathrm{n}=3$ 

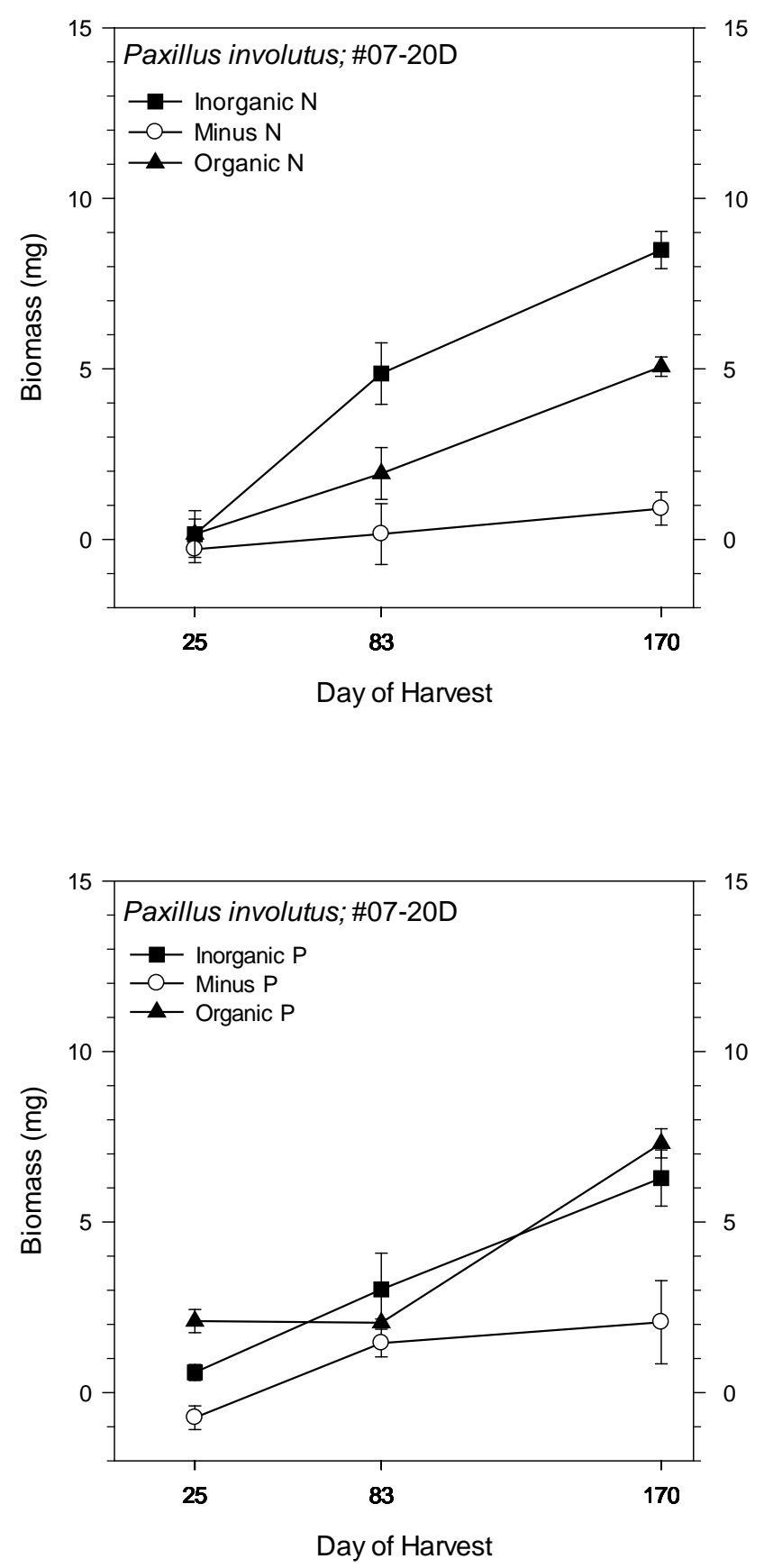

Figure 6 Pure culture growth rates (mean \pm SE) on three different $\mathrm{N}$ sources (top graph): minus $\mathrm{N}$ control (open circles), $\mathrm{NH}_{4} \mathrm{Cl}$ (closed squares), and bovine serum albumin (closed triangles) and on three different $\mathrm{P}$ sources (bottom graph): minus $\mathrm{P}$ control (open circles), $\mathrm{KH}_{2} \mathrm{PO}_{4}$ (closed squares), and phytic acid (closed triangles). $n=3$ 

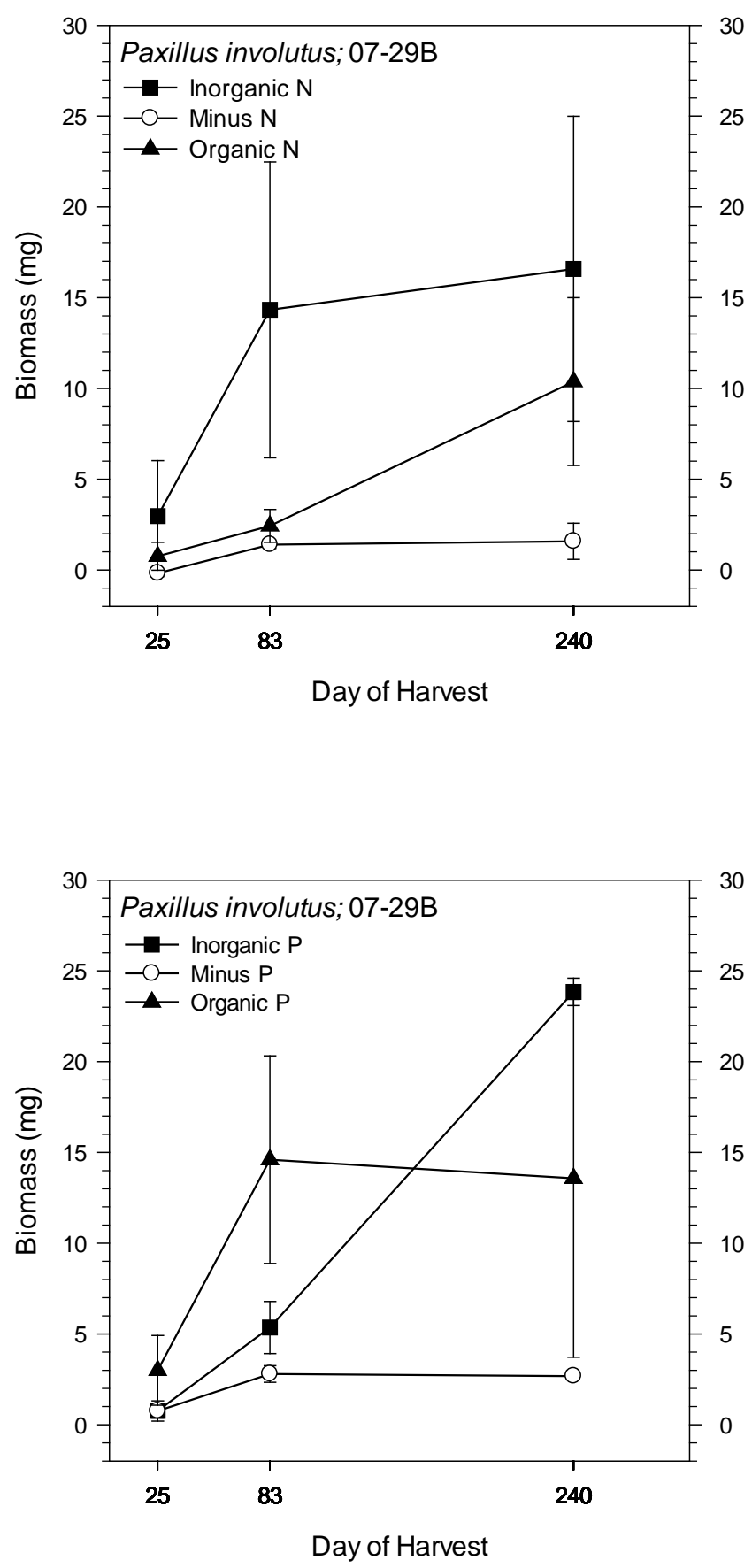

Figure 7 Pure culture growth rates (mean \pm SE) on three different $\mathrm{N}$ sources (top graph): minus $\mathrm{N}$ control (open circles), $\mathrm{NH}_{4} \mathrm{Cl}$ (closed squares), and bovine serum albumin (closed triangles) and on three different $\mathrm{P}$ sources (bottom graph): minus $\mathrm{P}$ control (open circles), $\mathrm{KH}_{2} \mathrm{PO}_{4}$ (closed squares), and phytic acid (closed triangles). $\mathrm{n}=3$ 

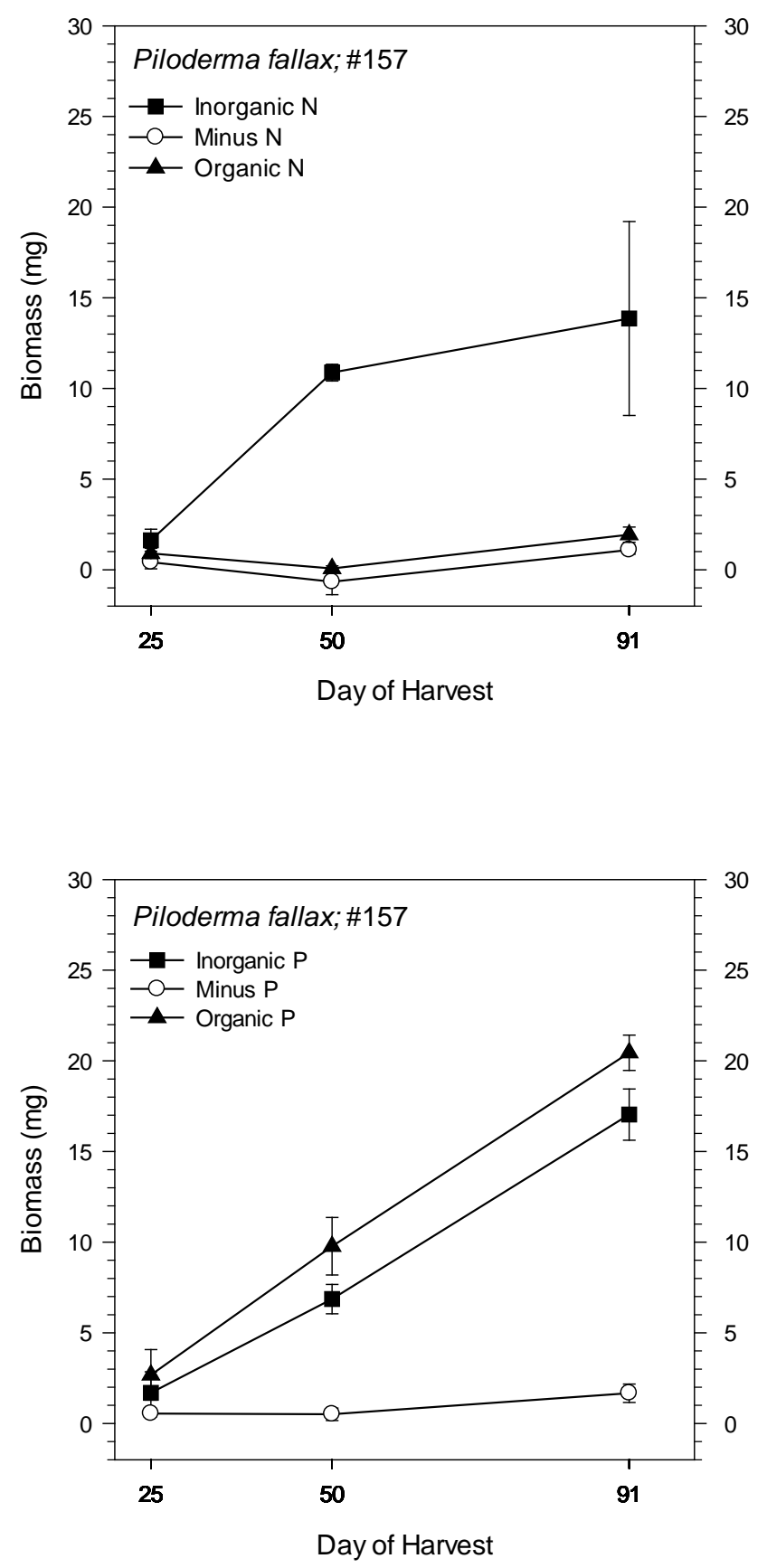

Figure 8 Pure culture growth rates (mean $\pm \mathrm{SE}$ ) on three different $\mathrm{N}$ sources (top graph): minus $\mathrm{N}$ control (open circles), $\mathrm{NH}_{4} \mathrm{Cl}$ (closed squares), and bovine serum albumin (closed triangles) and on three different $\mathrm{P}$ sources (bottom graph): minus $\mathrm{P}$ control (open circles), $\mathrm{KH}_{2} \mathrm{PO}_{4}$ (closed squares), and phytic acid (closed triangles). $\mathrm{n}=3$ 

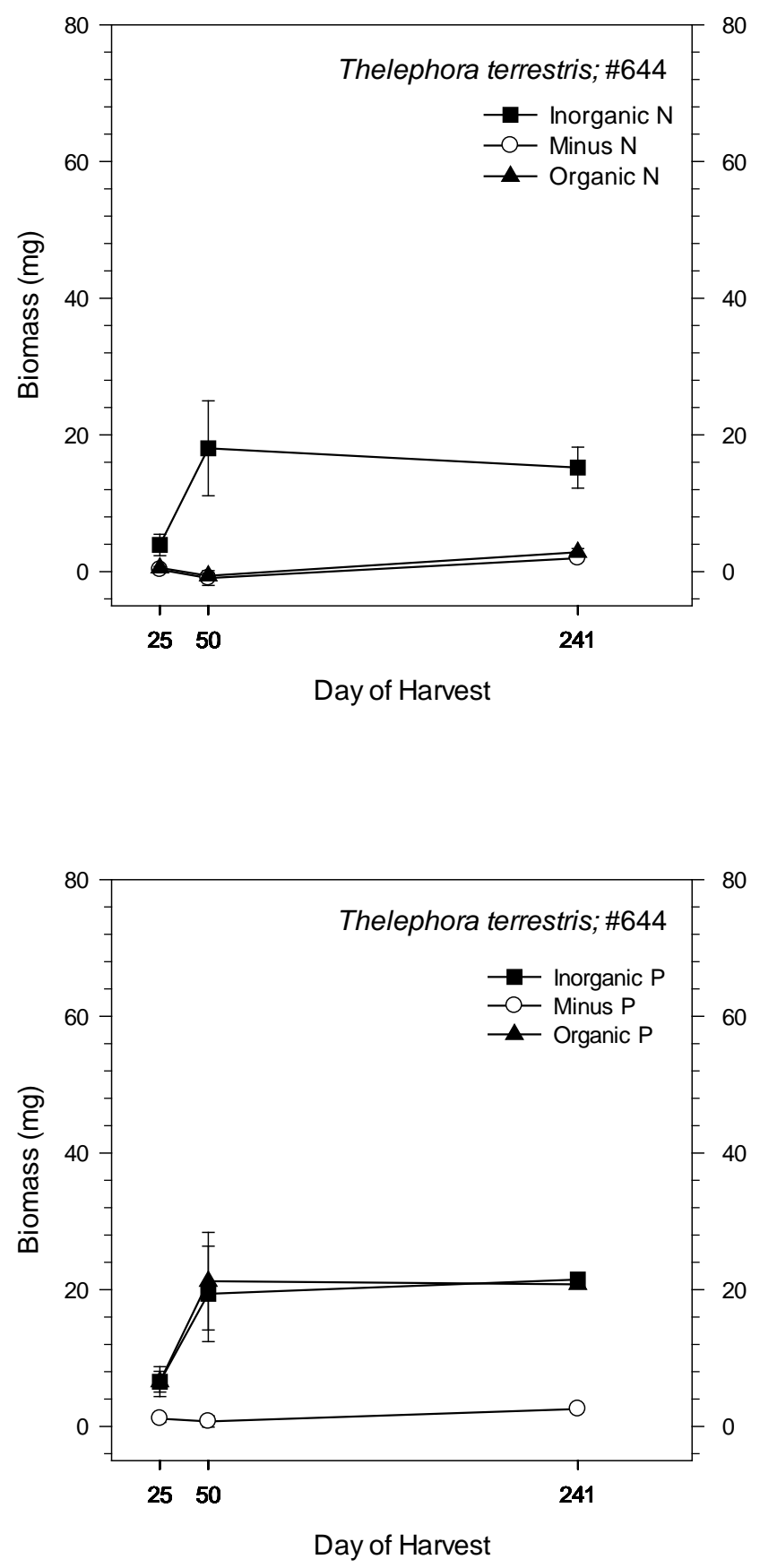

Figure 9 Pure culture growth rates (mean $\pm \mathrm{SE}$ ) on three different $\mathrm{N}$ sources (top graph): minus $\mathrm{N}$ control (open circles), $\mathrm{NH}_{4} \mathrm{Cl}$ (closed squares), and bovine serum albumin (closed triangles) and on three different $\mathrm{P}$ sources (bottom graph): minus $\mathrm{P}$ control (open circles), $\mathrm{KH}_{2} \mathrm{PO}_{4}$ (closed squares), and phytic acid (closed triangles). $\mathrm{n}=3$ 

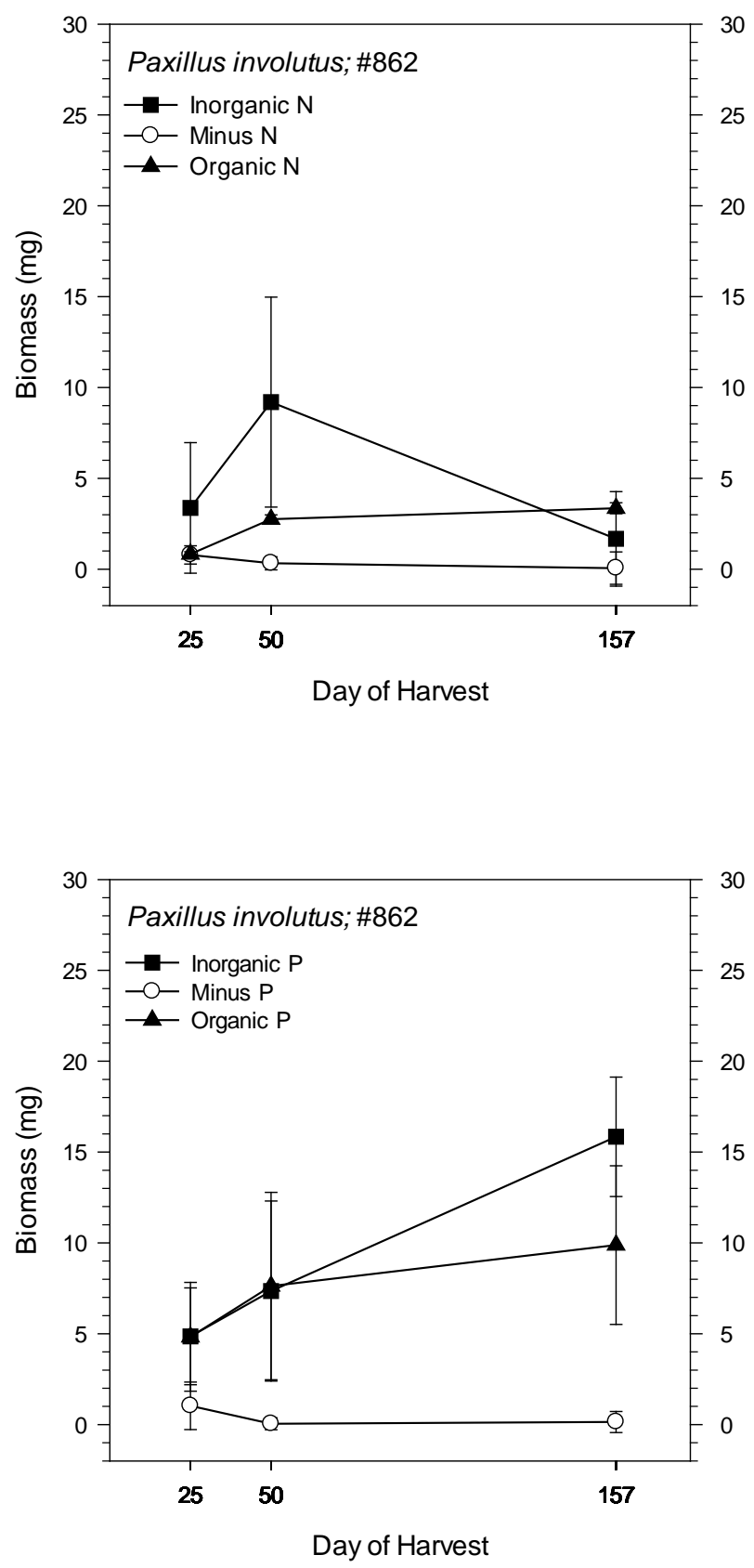

Figure 10 Pure culture growth rates (mean \pm SE) on three different $\mathrm{N}$ sources (top graph): minus $\mathrm{N}$ control (open circles), $\mathrm{NH}_{4} \mathrm{Cl}$ (closed squares), and bovine serum albumin (closed triangles) and on three different $\mathrm{P}$ sources (bottom graph): minus $\mathrm{P}$ control (open circles), $\mathrm{KH}_{2} \mathrm{PO}_{4}$ (closed squares), and phytic acid (closed triangles). $\mathrm{n}=3$ 

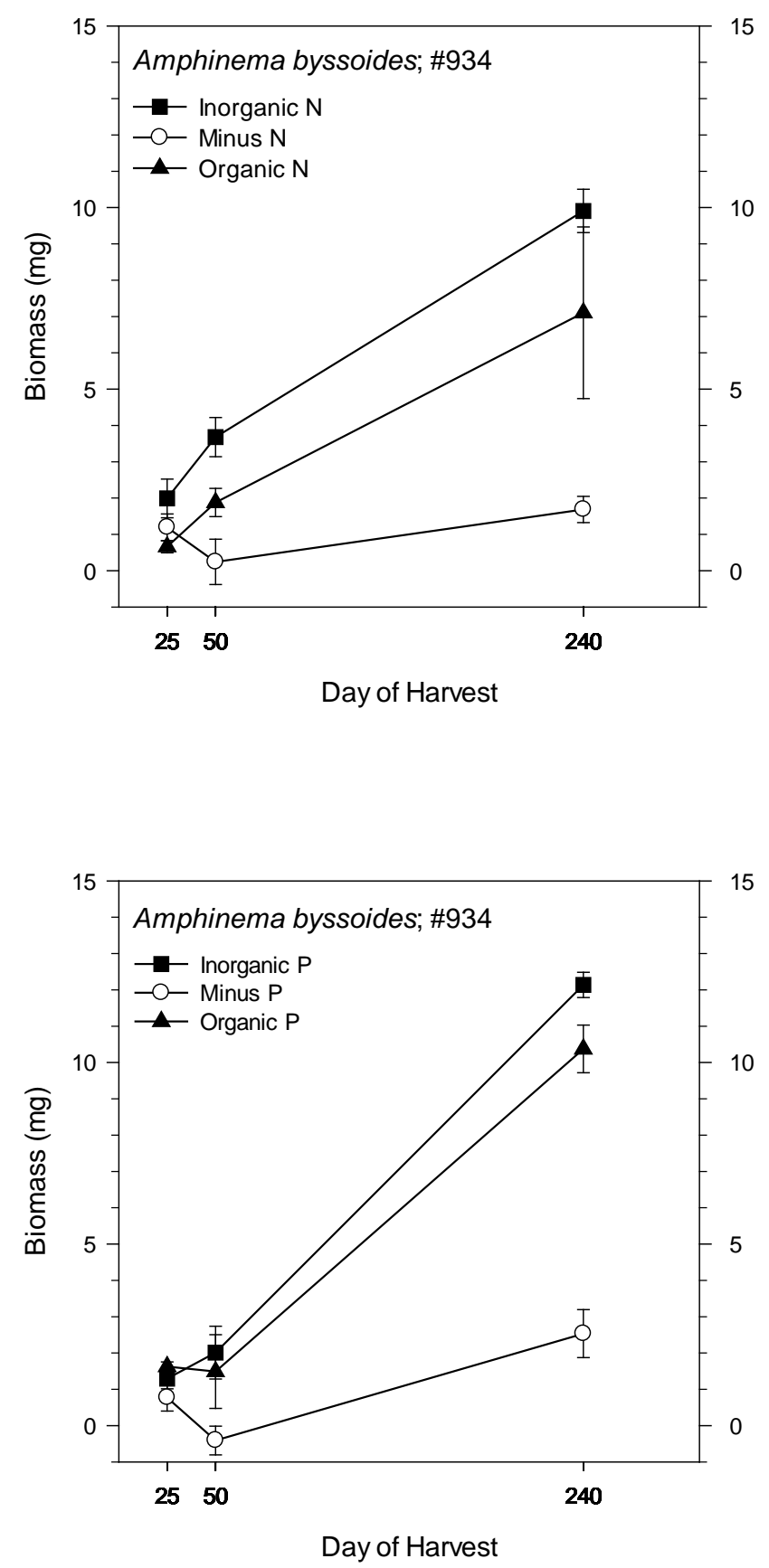

Figure 11 Pure culture growth rates (mean $\pm \mathrm{SE}$ ) on three different $\mathrm{N}$ sources (top graph): minus $\mathrm{N}$ control (open circles), $\mathrm{NH}_{4} \mathrm{Cl}$ (closed squares), and bovine serum albumin (closed triangles) and on three different $\mathrm{P}$ sources (bottom graph): minus $\mathrm{P}$ control (open circles), $\mathrm{KH}_{2} \mathrm{PO}_{4}$ (closed squares), and phytic acid (closed triangles). $\mathrm{n}=3$ 

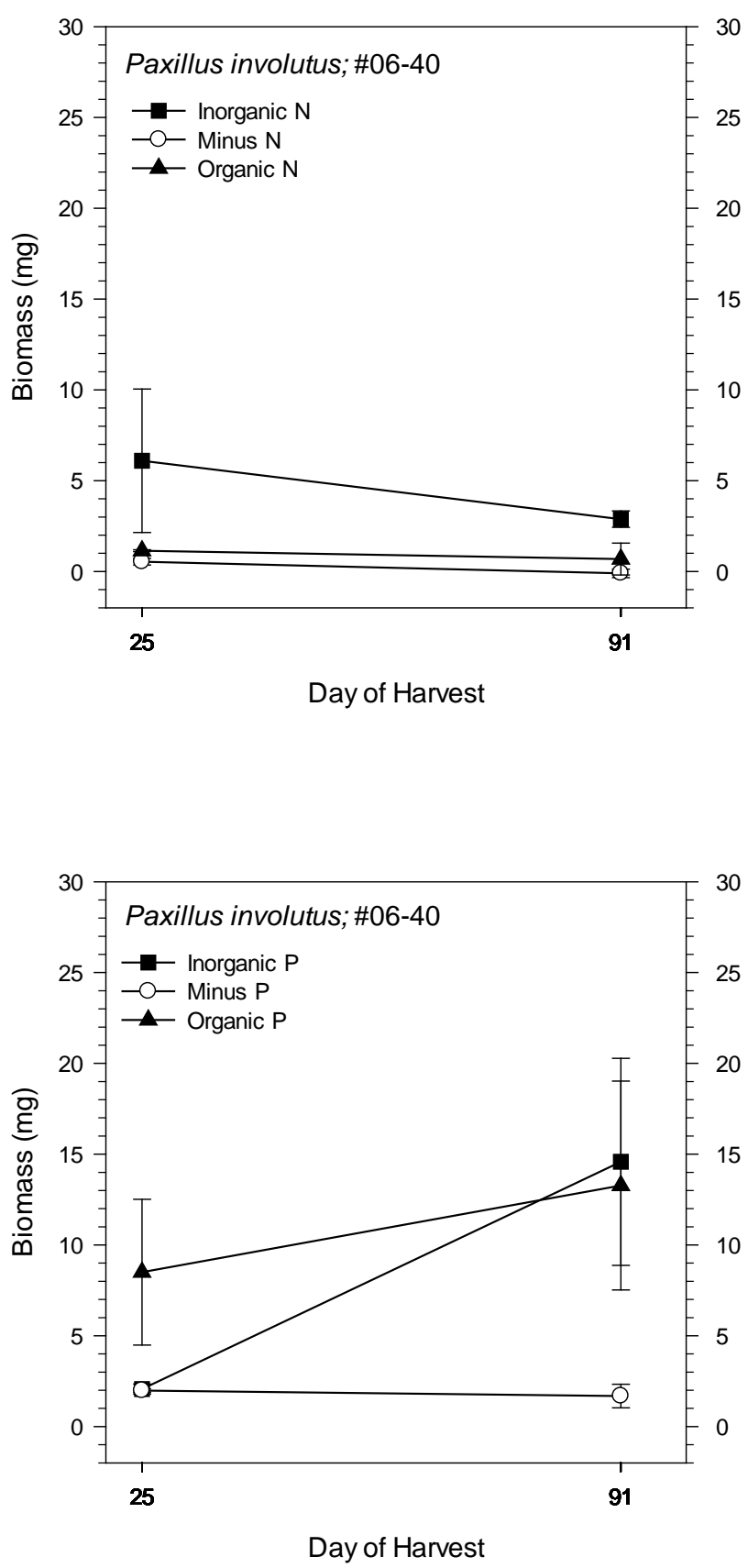

Figure 12 Pure culture growth rates (mean \pm SE) on three different $\mathrm{N}$ sources (top graph): minus $\mathrm{N}$ control (open circles), $\mathrm{NH}_{4} \mathrm{Cl}$ (closed squares), and bovine serum albumin (closed triangles) and on three different $\mathrm{P}$ sources (bottom graph): minus $\mathrm{P}$ control (open circles), $\mathrm{KH}_{2} \mathrm{PO}_{4}$ (closed squares), and phytic acid (closed triangles). $\mathrm{n}=3$ 

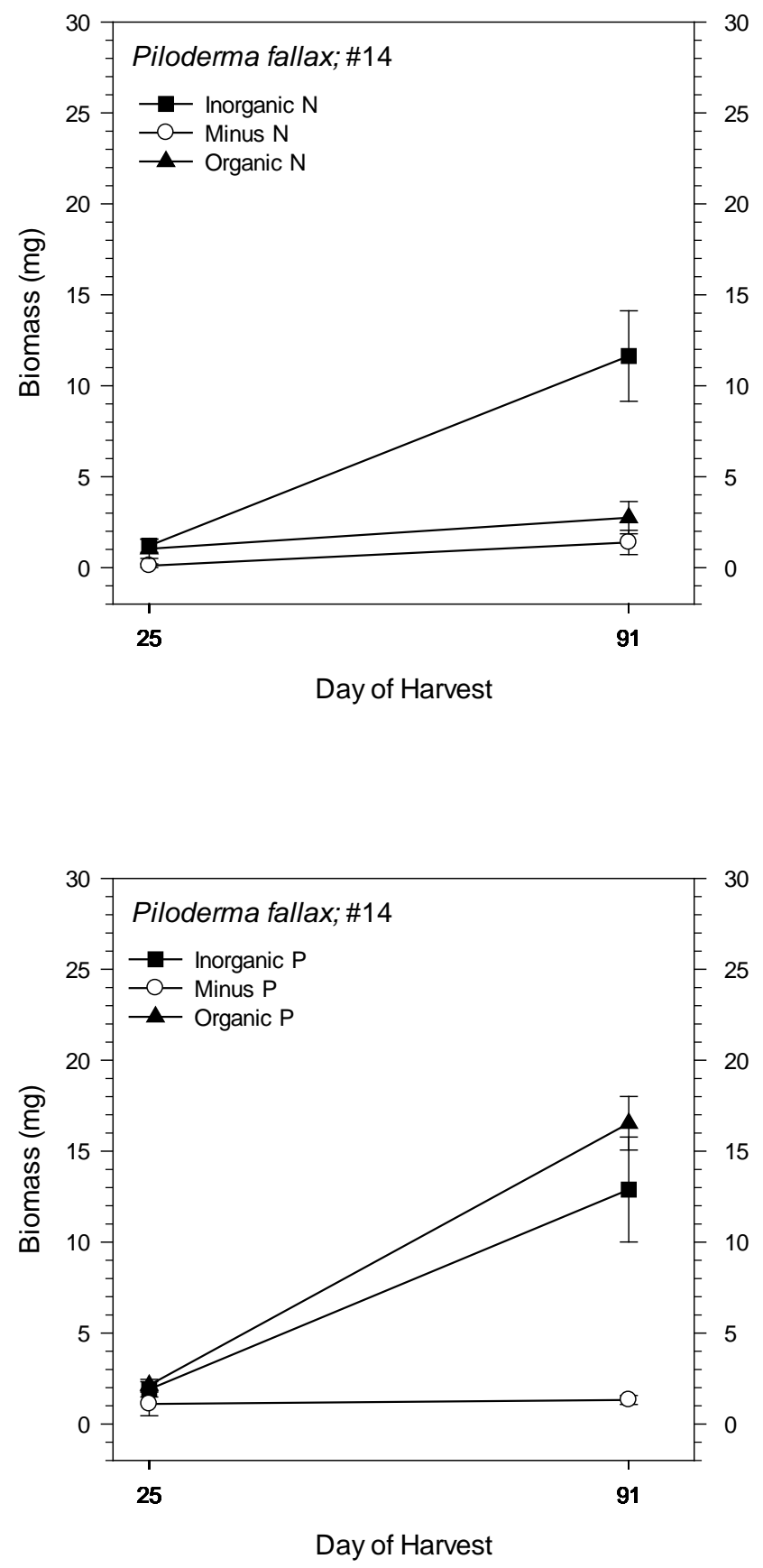

Figure 13 Pure culture growth rates (mean $\pm \mathrm{SE}$ ) on three different $\mathrm{N}$ sources (top graph): minus $\mathrm{N}$ control (open circles), $\mathrm{NH}_{4} \mathrm{Cl}$ (closed squares), and bovine serum albumin (closed triangles) and on three different $\mathrm{P}$ sources (bottom graph): minus $\mathrm{P}$ control (open circles), $\mathrm{KH}_{2} \mathrm{PO}_{4}$ (closed squares), and phytic acid (closed triangles). $\mathrm{n}=3$ 

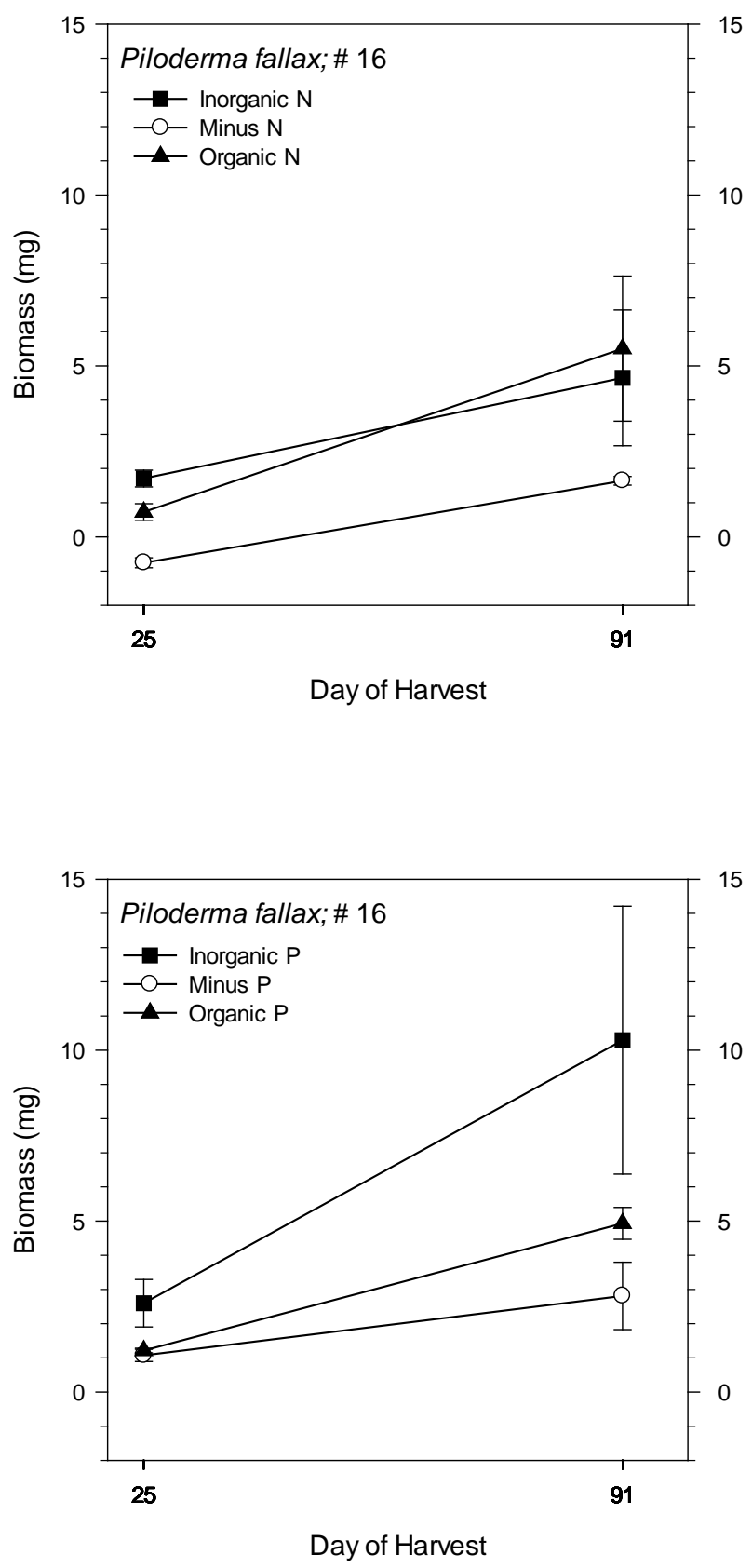

Figure 14 Pure culture growth rates (mean $\pm \mathrm{SE}$ ) on three different $\mathrm{N}$ sources (top graph): minus $\mathrm{N}$ control (open circles), $\mathrm{NH}_{4} \mathrm{Cl}$ (closed squares), and bovine serum albumin (closed triangles) and on three different $\mathrm{P}$ sources (bottom graph): minus $\mathrm{P}$ control (open circles), $\mathrm{KH}_{2} \mathrm{PO}_{4}$ (closed squares), and phytic acid (closed triangles). $\mathrm{n}=3$ 

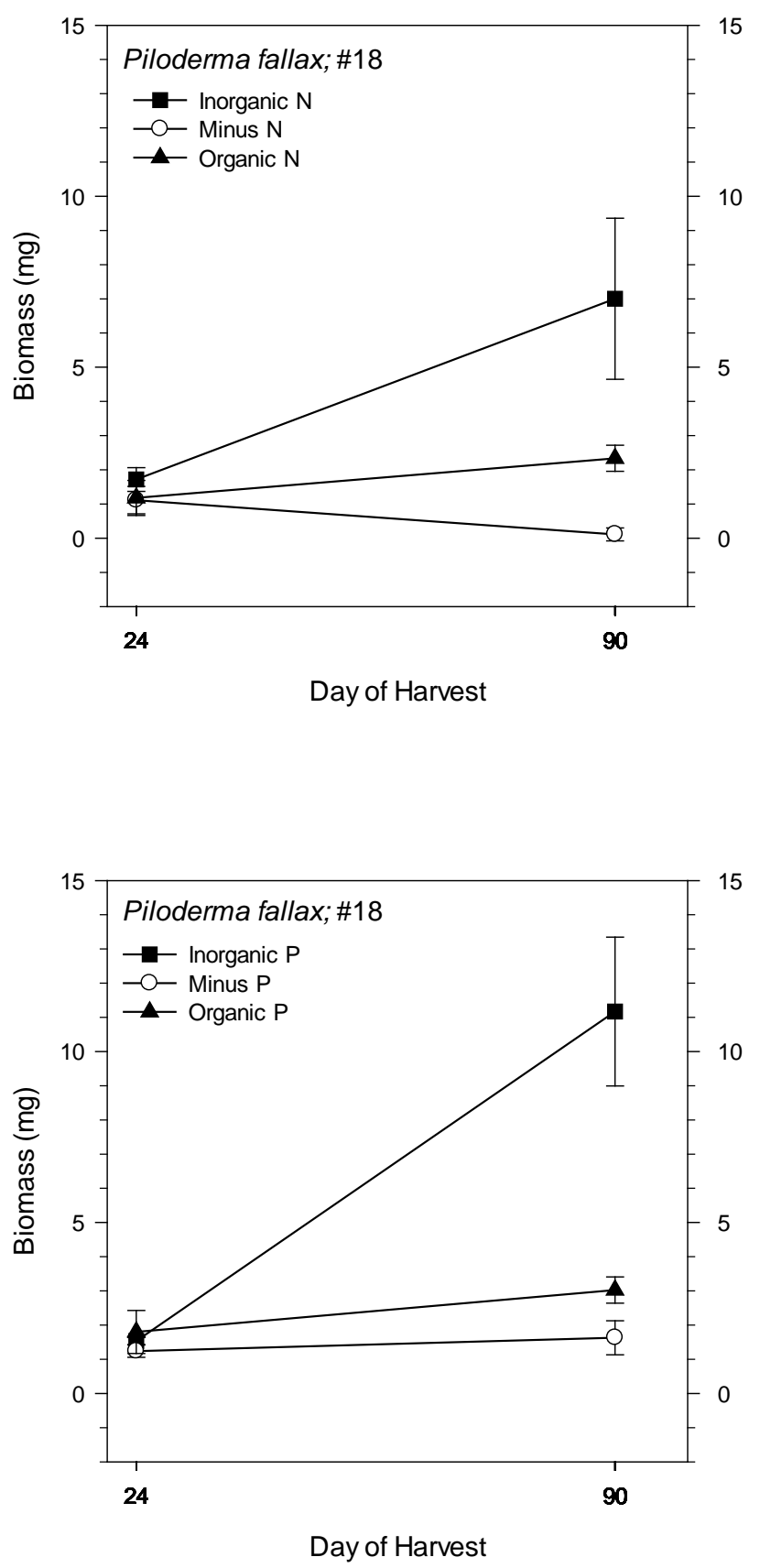

Figure 15 Pure culture growth rates (mean $\pm \mathrm{SE}$ ) on three different $\mathrm{N}$ sources (top graph): minus $\mathrm{N}$ control (open circles), $\mathrm{NH}_{4} \mathrm{Cl}$ (closed squares), and bovine serum albumin (closed triangles) and on three different $\mathrm{P}$ sources (bottom graph): minus $\mathrm{P}$ control (open circles), $\mathrm{KH}_{2} \mathrm{PO}_{4}$ (closed squares), and phytic acid (closed triangles). $\mathrm{n}=3$ 

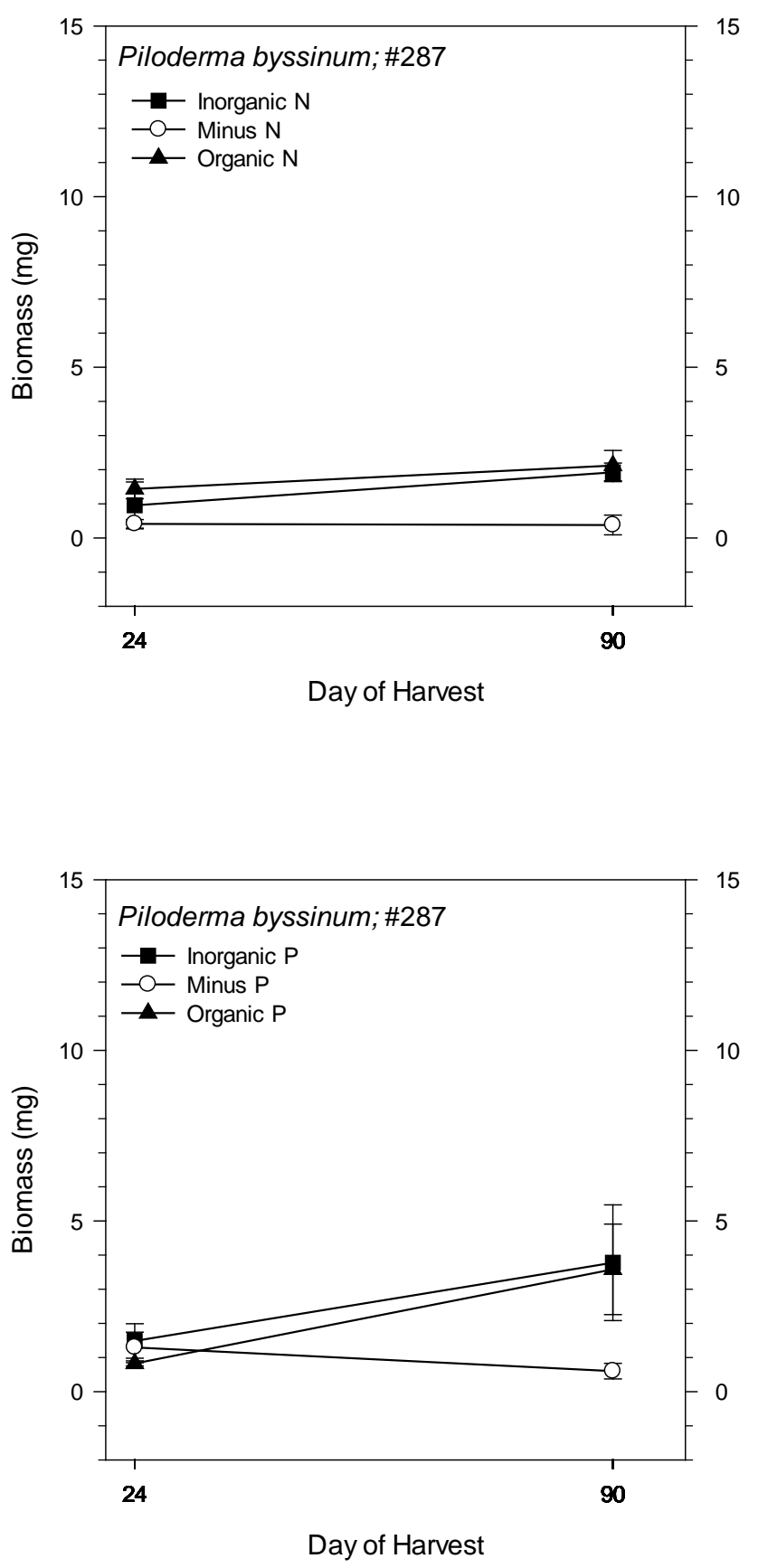

Figure 16 Pure culture growth rates (mean $\pm \mathrm{SE}$ ) on three different $\mathrm{N}$ sources (top graph): minus $\mathrm{N}$ control (open circles), $\mathrm{NH}_{4} \mathrm{Cl}$ (closed squares), and bovine serum albumin (closed triangles) and on three different $\mathrm{P}$ sources (bottom graph): minus $\mathrm{P}$ control (open circles), $\mathrm{KH}_{2} \mathrm{PO}_{4}$ (closed squares), and phytic acid (closed triangles). $\mathrm{n}=3$ 

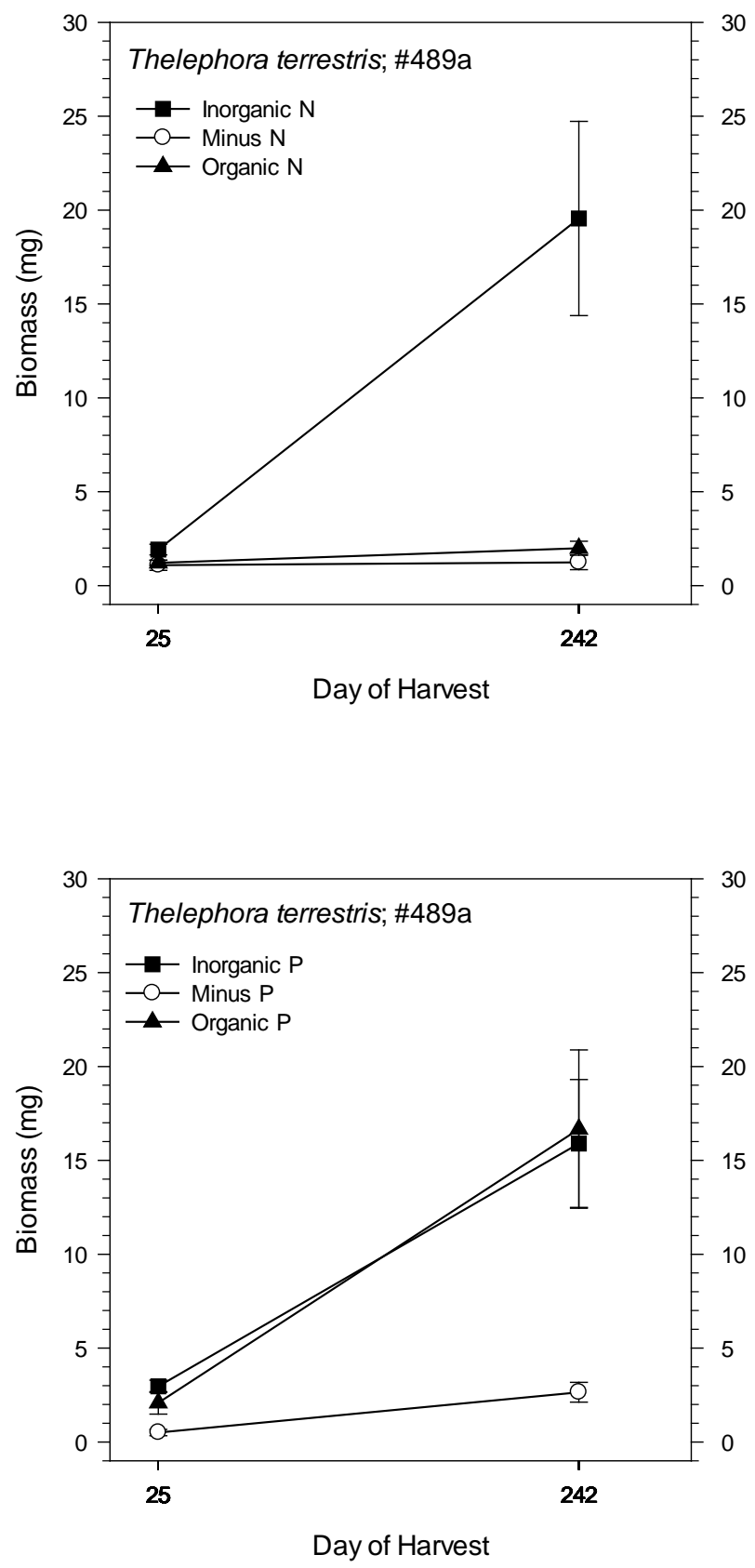

Figure 17 Pure culture growth rates (mean \pm SE) on three different $\mathrm{N}$ sources (top graph): minus $\mathrm{N}$ control (open circles), $\mathrm{NH}_{4} \mathrm{Cl}$ (closed squares), and bovine serum albumin (closed triangles) and on three different $\mathrm{P}$ sources (bottom graph): minus $\mathrm{P}$ control (open circles), $\mathrm{KH}_{2} \mathrm{PO}_{4}$ (closed squares), and phytic acid (closed triangles). $\mathrm{n}=3$ 

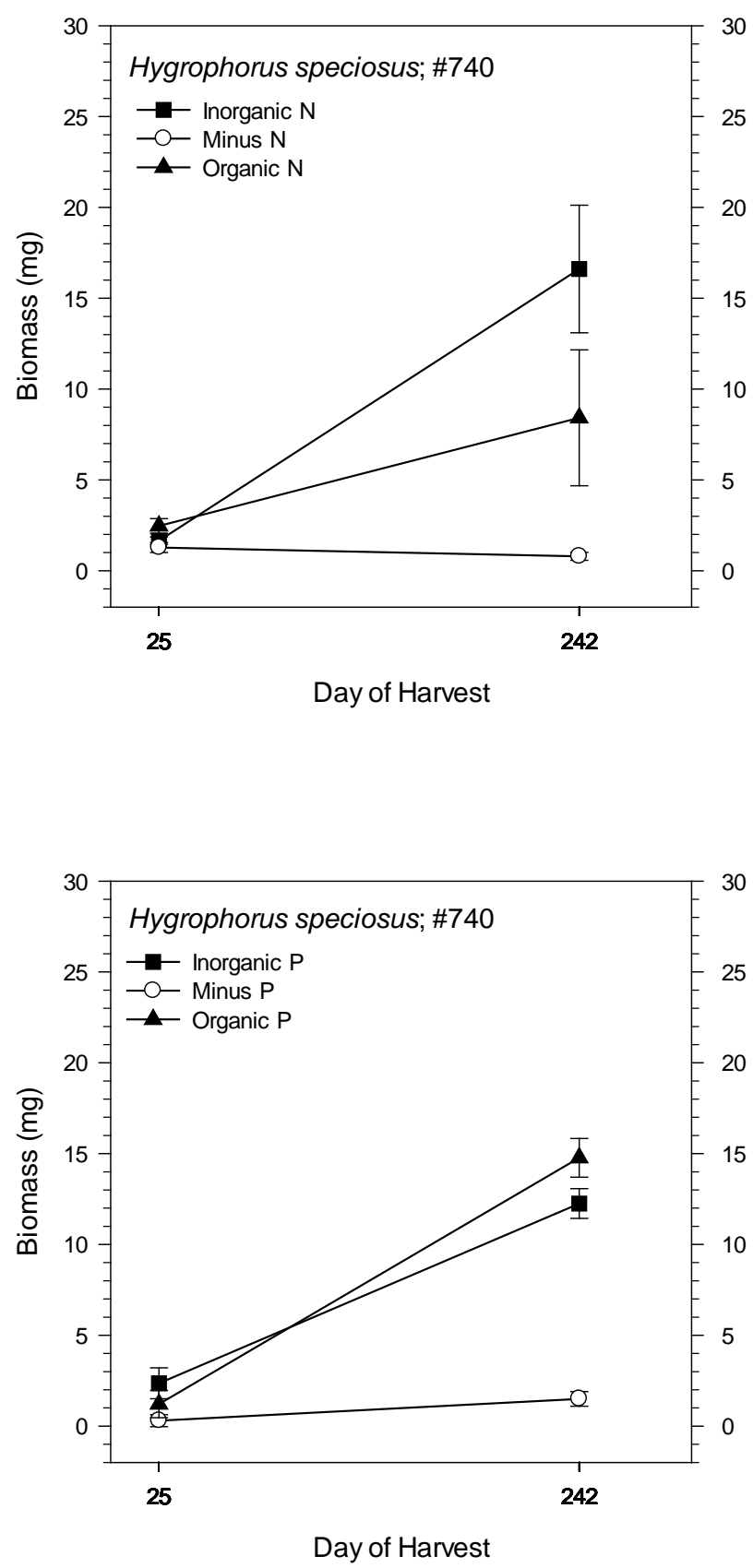

Figure 18 Pure culture growth rates (mean \pm SE) on three different $\mathrm{N}$ sources (top graph): minus $\mathrm{N}$ control (open circles), $\mathrm{NH}_{4} \mathrm{Cl}$ (closed squares), and bovine serum albumin (closed triangles) and on three different $\mathrm{P}$ sources (bottom graph): minus $\mathrm{P}$ control (open circles), $\mathrm{KH}_{2} \mathrm{PO}_{4}$ (closed squares), and phytic acid (closed triangles). $\mathrm{n}=3$ 

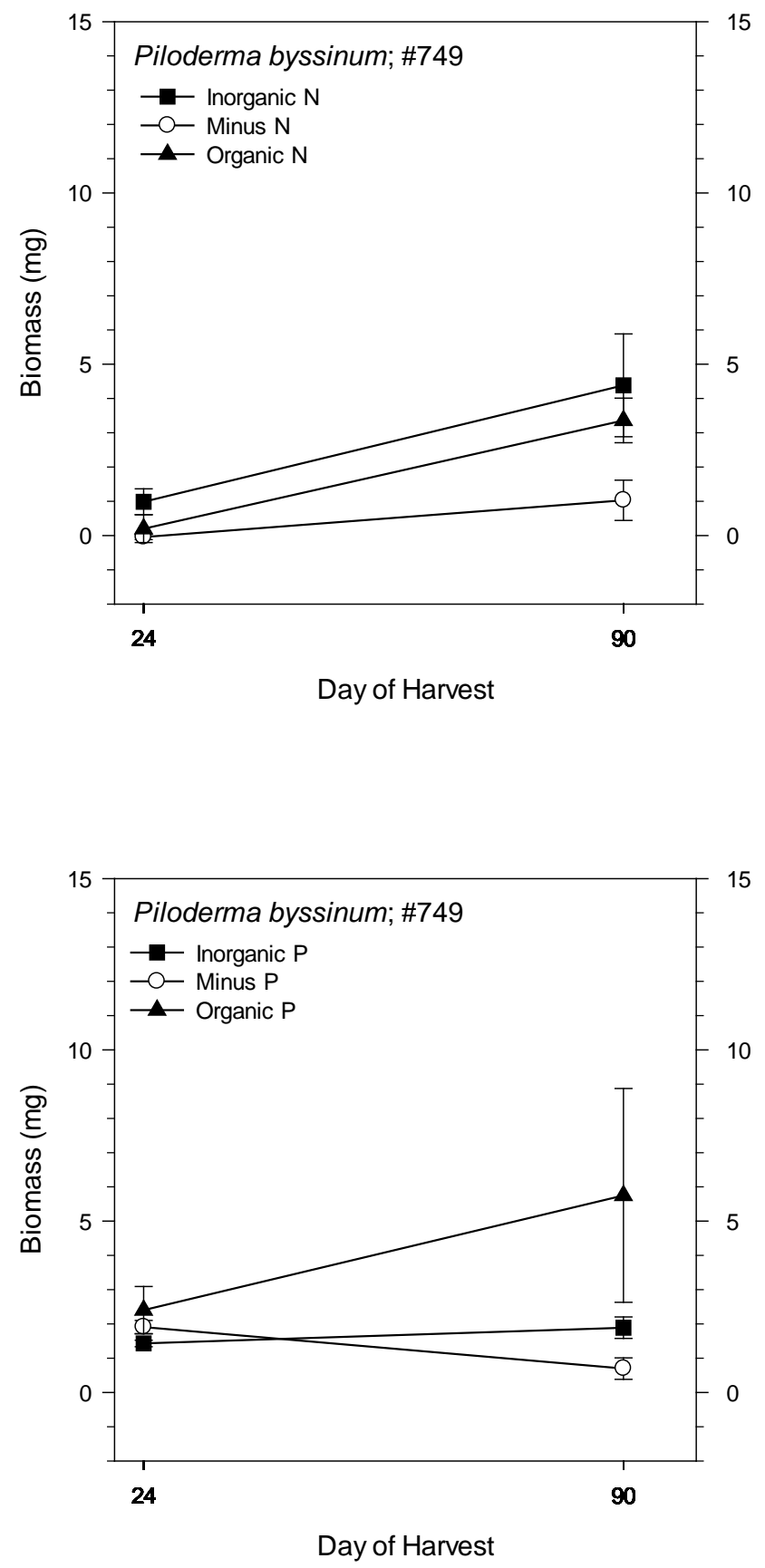

Figure 19 Pure culture growth rates (mean $\pm \mathrm{SE}$ ) on three different $\mathrm{N}$ sources (top graph): minus $\mathrm{N}$ control (open circles), $\mathrm{NH}_{4} \mathrm{Cl}$ (closed squares), and bovine serum albumin (closed triangles) and on three different $\mathrm{P}$ sources (bottom graph): minus $\mathrm{P}$ control (open circles), $\mathrm{KH}_{2} \mathrm{PO}_{4}$ (closed squares), and phytic acid (closed triangles). $\mathrm{n}=3$ 

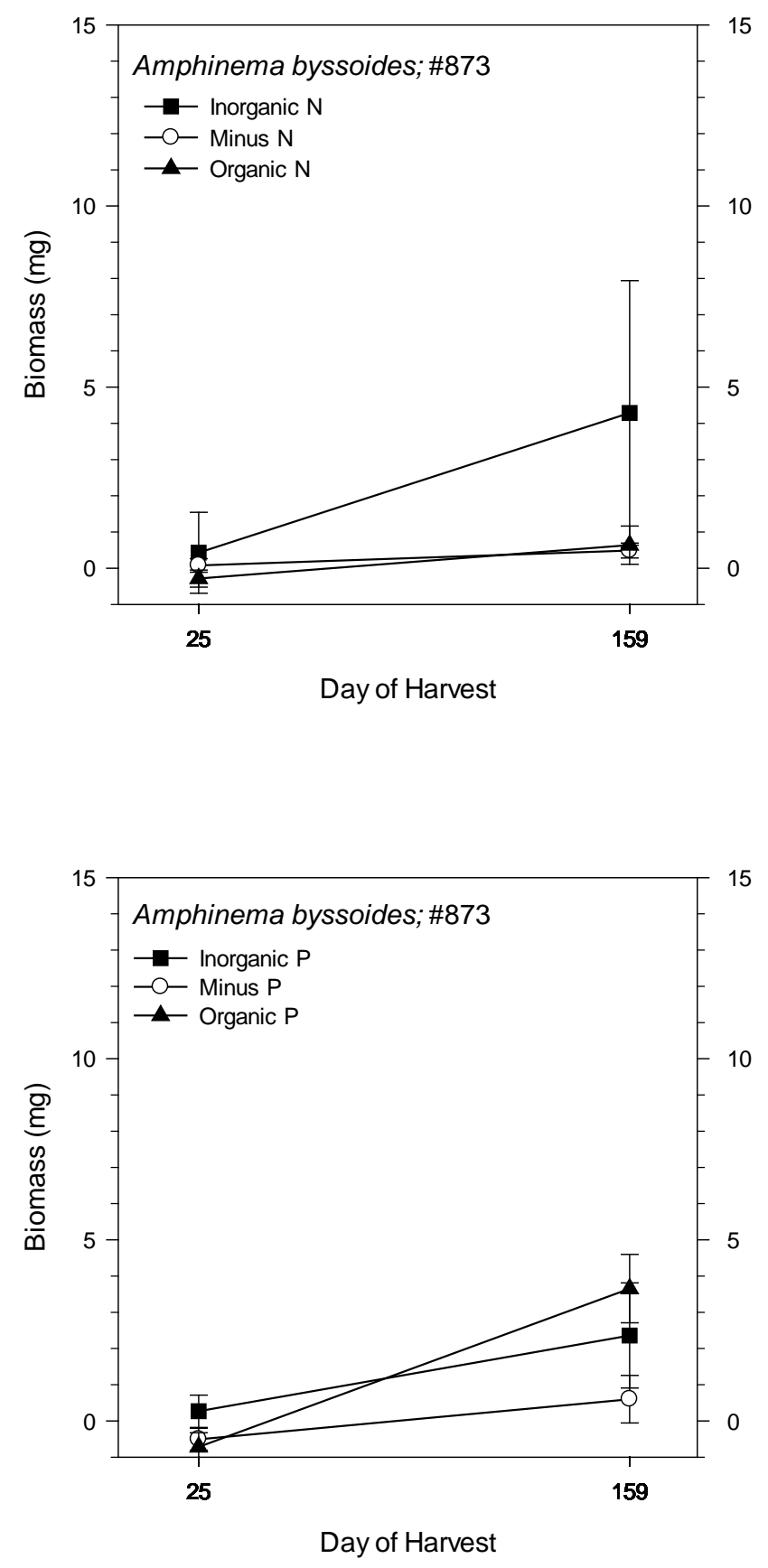

Figure 20 Pure culture growth rates (mean $\pm \mathrm{SE}$ ) on three different $\mathrm{N}$ sources (top graph): minus $\mathrm{N}$ control (open circles), $\mathrm{NH}_{4} \mathrm{Cl}$ (closed squares), and bovine serum albumin (closed triangles) and on three different $\mathrm{P}$ sources (bottom graph): minus $\mathrm{P}$ control (open circles), $\mathrm{KH}_{2} \mathrm{PO}_{4}$ (closed squares), and phytic acid (closed triangles). $\mathrm{n}=3$ 


\section{Appendices}

\section{Appendix 1}

\begin{tabular}{|c|c|c|}
\hline \multicolumn{3}{|c|}{$\begin{array}{l}\text { Induction Medium Protocol: The basal medium was } 10 \% \\
\text { strength MMN (Kottke et al. 1987) excluding malt extract and } \\
\text { ammonium phosphate. Ammonium chloride }\left(\mathrm{NH}_{4} \mathrm{Cl}\right) \\
\text { replaced the nitrogen source }(\mathrm{N}: \mathrm{P}=10) \text {, citrate buffer was } \\
\text { added to maintain the medium at } \mathrm{pH} 4.8 \text {, and glucose was } \\
\text { added to remain as the sole carbon source. }\end{array}$} \\
\hline Component & {$[1 \mathbf{x}]$} & units \\
\hline \multicolumn{3}{|l|}{ Macronutrients } \\
\hline $\mathrm{CaCl}_{2}$ & 5.0 & $\mathrm{mg} / \mathrm{L}$ \\
\hline $\mathrm{NaCl}$ & 2.5 & $\mathrm{mg} / \mathrm{L}$ \\
\hline $\mathrm{KH}_{2} \mathrm{PO}_{4}(1 / 20$ th $)$ & 2.5 & $\mathrm{mg} / \mathrm{L}$ \\
\hline $\mathrm{NH}_{4} \mathrm{Cl}(\mathrm{N}: \mathrm{P} \sim 10)$ & 25 & $\mathrm{mg} / \mathrm{L}$ \\
\hline $\mathrm{MgSO}_{4} 7 \mathrm{H}_{2} \mathrm{O}$ & 15 & $\mathrm{mg} / \mathrm{L}$ \\
\hline Fe EDTA & 5.0 & $\mathrm{mg} / \mathrm{L}$ \\
\hline \multicolumn{3}{|l|}{ Organic nutrients } \\
\hline Thiamine $\mathrm{HCl}$ & 0.01 & $\mathrm{mg} / \mathrm{L}$ \\
\hline Glucose & 500.0 & $\mathrm{mg} / \mathrm{L}$ \\
\hline \multicolumn{3}{|l|}{ Trace elements } \\
\hline $\mathrm{H}_{3} \mathrm{BO}_{3}$ & 15.46 & $\mathrm{mg} / \mathrm{L}$ \\
\hline $\mathrm{MnSO}_{4} * \mathrm{H}_{2} \mathrm{O}$ & 8.45 & $\mathrm{mg} / \mathrm{L}$ \\
\hline $\mathrm{ZnSO}_{4} * 7 \mathrm{H}_{2} \mathrm{O}$ & 5.75 & $\mathrm{mg} / \mathrm{L}$ \\
\hline $\mathrm{CuSO}_{4} * 5 \mathrm{H}_{2} \mathrm{O}$ & 1.25 & $\mathrm{mg} / \mathrm{L}$ \\
\hline $\mathrm{Na}_{2} \mathrm{MoO}_{4} \cdot 2 \mathrm{H}_{2} \mathrm{O}$ & 0.0352 & $\mathrm{mg} / \mathrm{L}$ \\
\hline \multicolumn{3}{|l|}{ Stock solution } \\
\hline 0.1M Citrate Buffer Stock & 100.0 & $\mathrm{ml} / \mathrm{L}$ \\
\hline
\end{tabular}




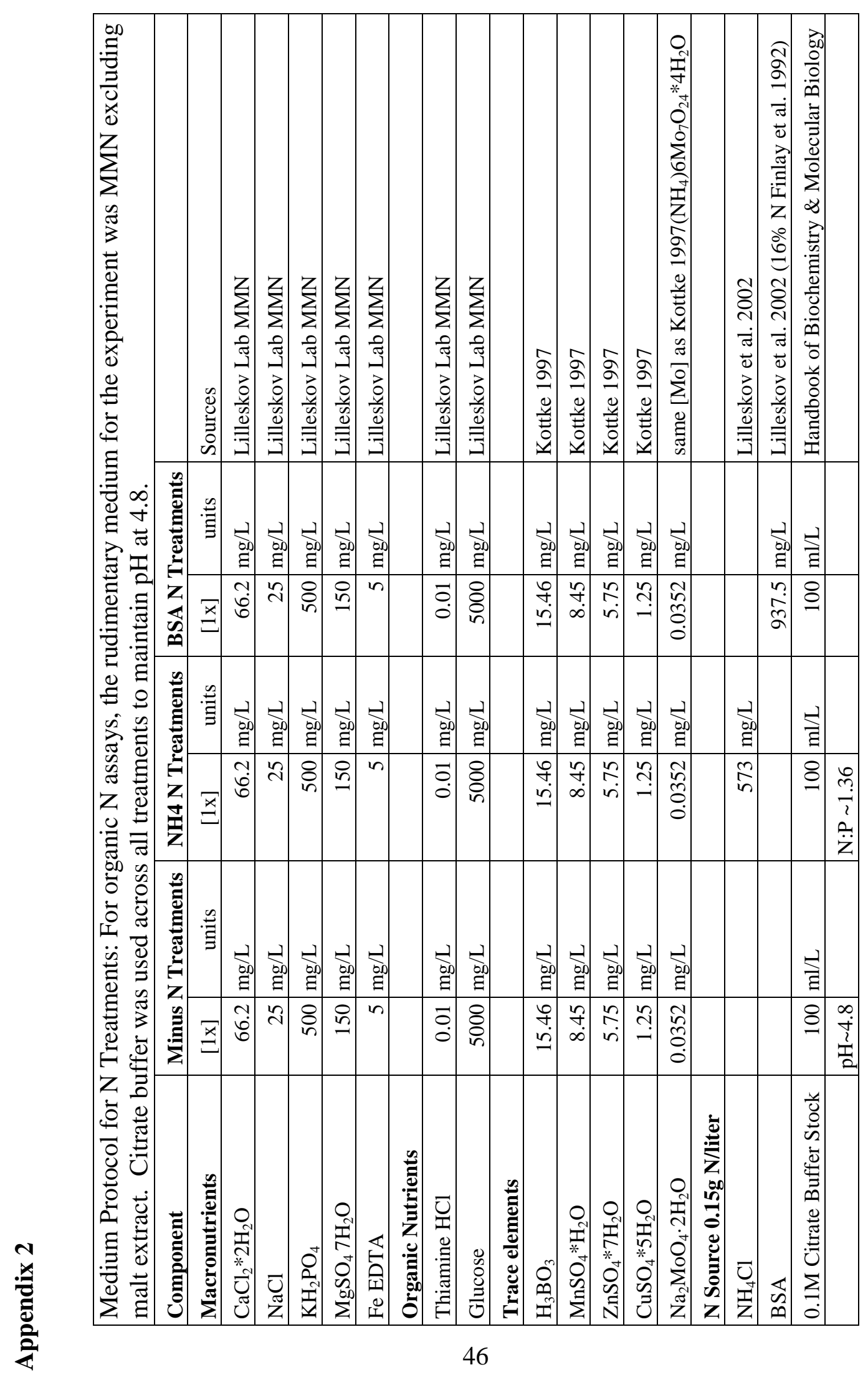




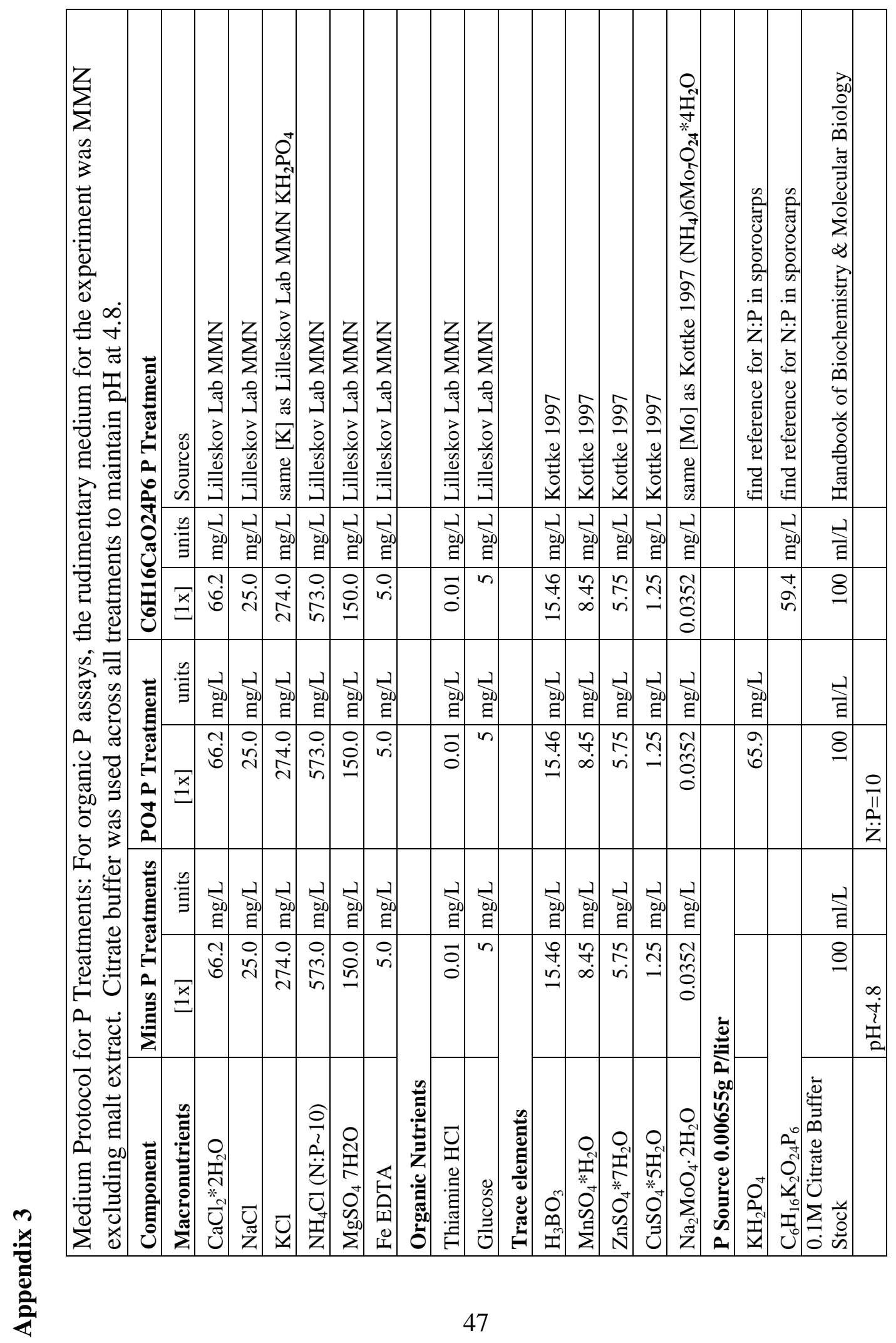




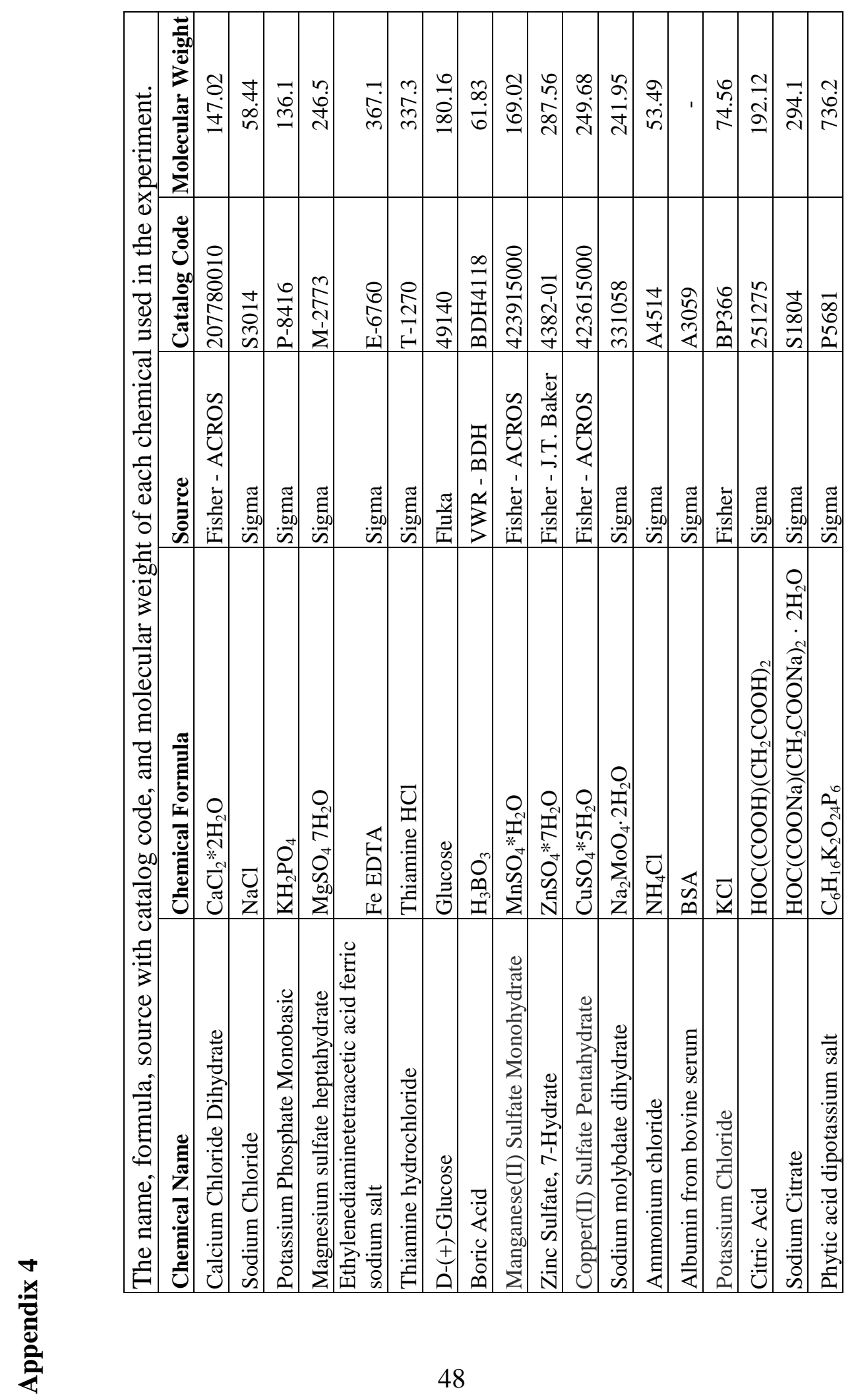




\section{Appendix 5}

GROWTH EXERIMENT METHODS 09012009

Preparatory Work

- $\quad$ Supply List

$\begin{array}{ll}\text { 1. } & \text { TEST TUBES } \\ \text { 2. } & \text { TEST TUBE RACKS } \\ \text { 3. } & \text { BSA } \\ \text { 4. } & \text { INOSITOL HEXAPHOSPHATE } \\ \text { 5. } & \text { FILTERS } \\ 6 . & \text { WIDE-MOUTH PINT BALL JARS }\end{array}$

- $\quad$ Rate Cultures

$$
\begin{aligned}
& 0=\text { no growth } \\
& 1=\text { growth barely present } \\
& 2=\text { some growth } \\
& 3=\text { definite growth } \\
& 4=\text { semi-substantial growth } \\
& 5=\text { substantial growth }
\end{aligned}
$$

- Decide on any cultures to expand on or eliminate

- $\quad$ Tubes will not be tightly closed to optimize gas exchange and they will be taped with Parafilm

- $\quad$ Mix at $\mathrm{pH} 4.8$ and pipette into tubes and autoclave:

1) MMN excluding $\mathrm{NH}_{4} \mathrm{Cl}$ and malt extract with glucose and citrate buffer

2) MMN excluding malt extract with glucose and citrate buffer

3) MMN excluding $\mathrm{NH}_{4} \mathrm{Cl}$ and malt extract with $\mathrm{BSA}$ added with glucose and citrate buffer

4) MMN excluding $\mathrm{KH}_{2} \mathrm{PO}_{4}$ and malt extract with glucose and citrate buffer

5) MMN excluding malt extract with glucose and citrate buffer

6) MMN excluding $\mathrm{KH}_{2} \mathrm{PO}_{4}$ and malt extract with inositol hexaphosphate (Cumming 1993; Colpaert et.al. 1997; Hayes et.al. 2000) and glucose and citrate buffer

- $\quad$ Select harvest dates (intervals) for each taxon

Process Date 1 (begin experiment):

- $\quad$ Blend liquid cultures in a Mason jar containing MMN liquid; let rest approximately two months

- $\quad$ Transfer by pipette each fungal isolate to nine test tubes of each growth medium and three to pre-weighed X mm filters for vacuum filtration and oven drying. This translates as each isolate must contain enough biomass to accommodate three filters and 54 test tubes allowing for three test tubes to be harvested from each growth treatment on three dates.

- $\quad$ Loosely screw down the test tube caps and parafilm.

- $\quad$ Store racks of test tubes in an incubator set at $15^{\circ} \mathrm{C}$

- Vacuum filter and wash with R.O. water three samples of each isolate in each treatment on a pre-weighed X mm filter; fold filter in half with forceps and place in labeled foil folders

- $\quad$ Freeze filters

- $\quad$ Freeze dry filters for 24 hours

- $\quad$ Place freeze dried filters into dessicators for 24 hours

- $\quad$ Weigh filters on a micro balance

Process Dates 2, 3, \& 4:

- $\quad$ Randomly select three tubes of each isolate from each growth treatment

- $\quad$ Vacuum filter and wash with R.O. water three samples of each isolate in each treatment on a pre-weighed X mm filter; fold filter in half with forceps and place in labeled foil folders

- $\quad$ Freeze filters

- $\quad$ Freeze dry filters for 24 hours

- $\quad$ Place freeze dried filters into dessicators for 24 hours

- $\quad$ Weigh filters on a micro balance Statistical Analysis in Minitab15

- $\quad$ Culture growth in the treatments compared to minus-N controls $\rightarrow$ ANOVA, DUNNETT

- $\quad$ Culture growth in the treatments compared to minus-P controls $\rightarrow$ ANOVA, DUNNETT 